\title{
Evaluation of Water Resources Quality in Sabodala Gold Mining Region and Its Surrounding Area (Senegal)
}

\author{
Mall Ibrahima*, Diaw Moctar, Dieng Ndèye Maguette, Madioune Hélène Diakher, \\ Ngom Papa Malick, Faye Serigne \\ Département de Géologie, Faculté des Sciences et Technique, Université Cheikh Anta DIOP, Dakar, Sénégal \\ Email: ${ }^{*}$ ibrahimamall@yahoo.fr, ${ }^{*}$ ibrahimama.mall@uacd.edu.sn
}

Received 1 February 2015; accepted 16 February 2015; published 27 February 2015

Copyright (C) 2015 by authors and Scientific Research Publishing Inc.

This work is licensed under the Creative Commons Attribution International License (CC BY). http://creativecommons.org/licenses/by/4.0/

cc) (i) Open Access

\begin{abstract}
Geochemical and Geostatistical tools were used to assess: 1) the chemical quality and, geochemical processes in crystalline rock aquifers in Sabodala (Eastern Senegal) and its surroundings and 2) the impact of mining activities on their quality. A total of 26 water samples collected at boreholes, dug wells and stream, were analyzed to determine major and trace elements concentration focused on elements that represent more threats on human health. Boxplots define chemical characteristics of water for each aquifer formation compared to surface waters. Geostatistical analysis show two sources of water mineralization with regard to major elements: a first natural source characterized by $\mathrm{Ca}-\mathrm{Mg}-\mathrm{HCO}_{3}$ water type from boreholes and unpolluted surface water and a second

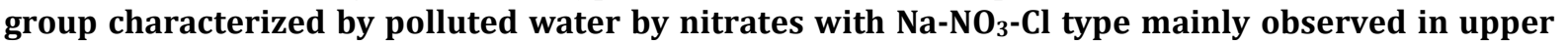
weathered aquifers. However, considering trace element, geostatistical analysis showed three water groups: water with very low trace element concentrations encountered in boreholes and unpolluted surface waters, and waters with relatively high trace element concentrations such as Al observed in areas affected by gold mining activities and finally, polluted waters by $\mathrm{Ni}$, Co, Mn and $\mathrm{Cr}$ observed at Sabodala. Results show that in eastern Senegal well waters are vulnerable and often affected by pollution.
\end{abstract}

\section{Keywords}

Geochemistry, Geostatistical, Crystalline Rock Aquifer, Pollution, Trace Elements, Sabodala, Senegal

\footnotetext{
${ }^{*}$ Corresponding author.
} 


\section{Introduction}

The study area is located in the basement part of Senegal; it is constituted by Birimian formations that are gold bearing such as in most part of West africancraton. These terrains have experienced since the 70s a great development of gold research which is crowned by gold mining, discovery and exploitation of Sabodala gold deposit and its satellites which reserves are estimated at several tons of gold. The Birimian's Gold is obviously the main wealth in the South eastern Senegal. Excepted in the large granite massif of Saraya, gold is present on the entire Birimian formations [1] as evidenced by many gold mining sites. Today, mining companies' implantation has led to a rapid development of some villages by a massive influx of people coming from all regions of Senegal and neighboring countries seeking for job on industries or traditional gold mining and even making business. With regard to this situation, water demand and uses is increasing due to the great amount of water used by extractive industry and traditional miners for ore processing. This latter could seriously damage the quality of this resource as mercury is widely used in treatment processing like gold washing and leaching of metallic trace elements (MTE). In fact, MTE constitute the main source of water pollution that affect their quality. According to [2] Nriagu (1990b), MTE contamination has two main origins: 1) a natural source mainly derived from weathering of rocks and atmosphere inputs via volcanic activity which represents $80 \%$ of all the natural sources, compared by forest fires and biogenic sources accounting 10\% each; 2) an anthropogenic source mainly derived from the mining activities that can contribute significantly to enrich MTE in waters. This study is aimed to determine water resources quality in relation to the geological nature birimian terrains as well as anthropogenic activities impact related to both industrial and traditional gold mining. The methodological approach based on use of geostatistical tools [3] [4] by PCA (principal components analysis) was conducted on various chemical and physico-chemical parameters in order to discriminate: water chemistry depending on geology of different aquifer types (granites, mafic volcanic rocks, shistes and volcano-sediment) and further anthropogenic inputs induced by mining activities in the sector. Hierarchical cluster analysis (HCA) and the Ward jump, as well as a representation of classes by the biplot function have been used to identify water classes that have enabled to determine the various changes in the chemical water composition that could compromise their quality for human consumption.

\section{Study Area}

The study area is located in the south-eastern part of Senegal and belong in the administrative regions of Tambacounda and Kédougou between latitudes $12^{\circ} 30^{\prime}$ and $13^{\circ} 45^{\prime}$ North and longitudes $11^{\circ} 30^{\prime}$ and $12^{\circ} 30^{\prime}$ West. The geological terrains consist essentially by Birimian formations and are subdivided into two super groups as described by [5]:

- The Mako super group composed of thick mafic volcanic flows, massive ultramafic, gabbro and andesitic flows interbedded with quartzites and limestones. This complex is overlain by clastic volcano-sediments rocks made up of pyroclastic, greywackes, sandstones and mudstones [6]. The Mako Super group is folded according to an isocline type structure with a stratification generally concordant with the schistosity, it is characterized by a steeply subvertical dip or inclined to the NW;

- The Dialé-Dalema super group is composed of marbles which are overlain by quartzites, greywackes, sandstones and mudstones interbedded with andesitic flows of the Dialé group. This latter is inclined to the south-east with asymmetrical folds which axial plane shows a steeply dipping towards the north-west. The Dialé group is overlapped by Mako Super group at its western side.

A recent study project aimed to update the regional mapping of the region [7] divides the Birimian into three groups: Dialé, Mako and Daléma. These Birimian terrains have been investigated for several years for gold, iron and other minerals exploration (Figure 1). This is due to the fact that, the Birimian rocks are known to bear proven ore deposed as well as gold indices in the region and in neighbouring countries. Sustrac [8] with regard to the number of small-scale mining and the discovery of gold indices characterized this zone as being favorable for industrial concentrations of this metal.

The study area is characterized by a dry season from October to April-May and a rainy season, which usually starts at the end of April and continues till October with a maximum rainfall occurring in August. The yearly average rainfall is about $1200 \mathrm{~mm}$ at the Kédougou station [9]. Rainfall quantity increases from north to south, whereas evaporation and temperature show an inverse trend, compared to rainfall gradient causing a precocious drying up of surface water reserves as early as February in the North province [10]. Hydrogeological context of 


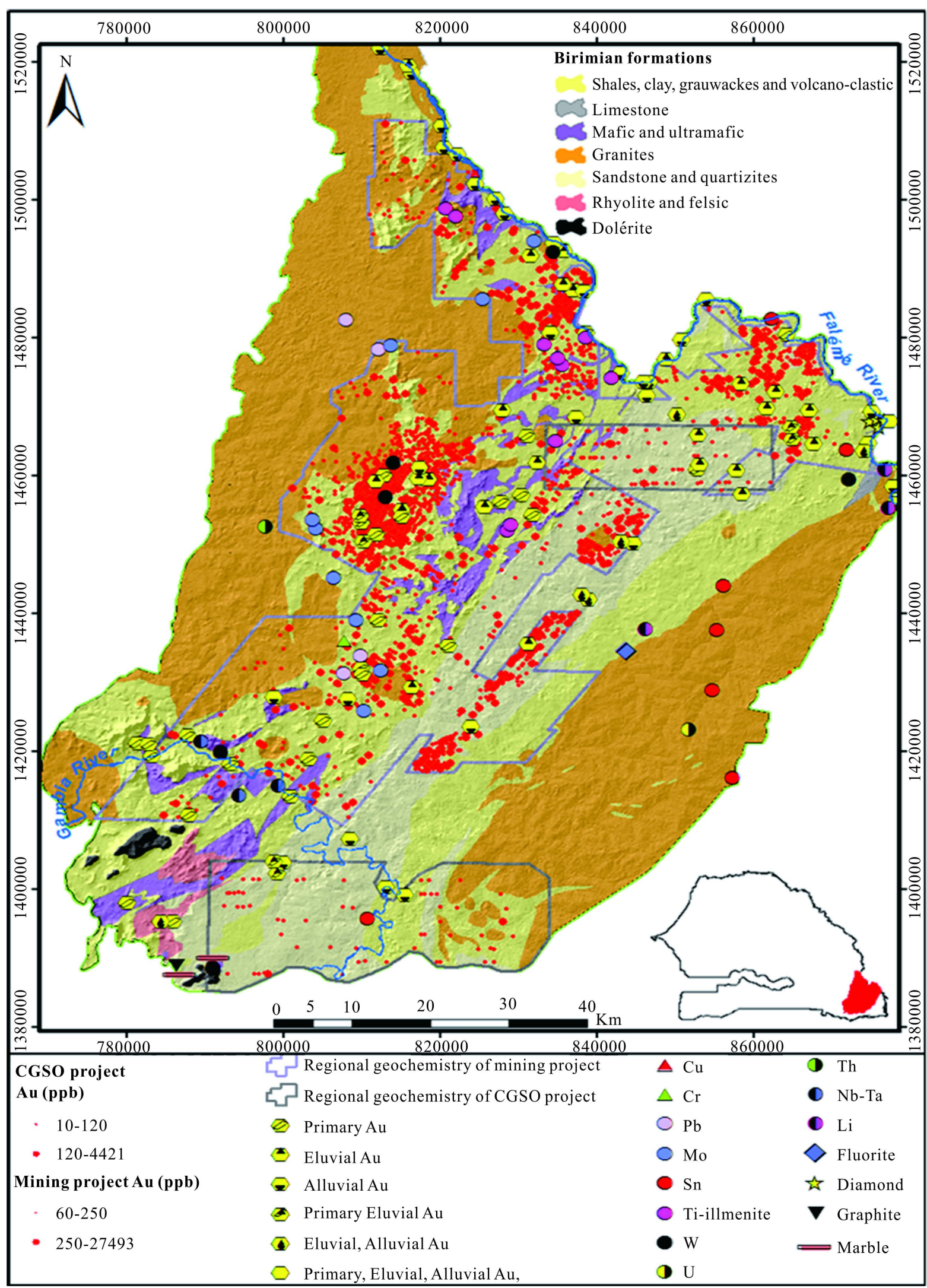

Figure 1. Metal and gold occurrence map of Birimian formations in eastern Senegal [1] (modified). 
the area is characterized by fractured, discontinuous and semi-continuous aquifers which are represented by the weathered fringe of hard rocks with yields varying from 0.6 to $30 \mathrm{~m}^{3} / \mathrm{h}$ and high rate of unsuccessful drilling [11].

\section{Materials and Methods}

Sampling campaign conducted in January 2011 investigated groundwaters and surface waters from different sites. Samplings were carried out on two aquifer systems (upper weathered aquifers that are exploited by village wells and lower fissured and fractured aquifers tapped by boreholes) and surface waters. A total of 26 samples was collected and distributed on different hydrogeological units and surface waters (Figure 2). Physico-chemical parameters such as $\mathrm{pH}$, temperature, dissolved oxygen and electric conductivity were measured in the field. Samples were filtered through 0.45 microns cellulose acetate filters, acidified with concentrated nitric acid and then stored at $4^{\circ} \mathrm{C}$ for analysis of major cations and trace elements. Samples for anions analysis were not acidified. Major cations and anions analysis were carried out using Dionex chromatography equipped with auto sampler. Analysis of trace elements was performed by ICP-MS (Inductively Coupled Plasma Mass Spectrometry) that enables measuring simultaneously concentrations of a number of chemical elements with low detection limits (DL) (often less than $0.1 \mathrm{ppb}$ ) [12]. The samples were measured with Agilent 7500cx ICP MS using the MERCK ICP multi-element standard solution X, the Inorganic Ventures IV-ICPMS-71A in three different dilution steps $(10 \mathrm{mg} / \mathrm{L}, 10 \mu \mathrm{g} / \mathrm{L}, 10 \mathrm{ng} / \mathrm{L})$ and a self-made standard from single element MERCK ICP standards of $\mathrm{Si}, \mathrm{Al}, \mathrm{Ge}, \mathrm{Sb}$ and Ti. Each measurement consisted of five repetitions. Concentrations and standard deviations were given in Table 5. Principal components analysis (PCA) was conducted on various chemical parameters $\left(\mathrm{Ca}^{2+} \mathrm{Mg}^{2+}, \mathrm{Na}^{+}, \mathrm{K}^{+}, \mathrm{HCO}_{3}^{-}, \mathrm{NO}_{3}^{-}, \mathrm{Cl}^{-}, \mathrm{SO}_{4}^{2-}, \mathrm{Si}_{4}^{+}, \mathrm{As}, \mathrm{Cd}, \mathrm{Cr}, \mathrm{Co}, \mathrm{Cu}, \mathrm{Fe}, \mathrm{Pb}, \mathrm{Mn}, \mathrm{Zn}, \mathrm{Ni}, \mathrm{Al}\right)$ and physico-chemical ( $\mathrm{pH}, \mathrm{T}^{\circ} \mathrm{C}$, dissolved $\left.\mathrm{O} 2, \mathrm{Eh}\right)$ in order to determine different origins of water mineralization. In addition, hierarchical cluster analysis (HCA) and the Ward jump with representation of classes by the biplot function were used to identify the different water classes.

\section{Results and Discussion}

\subsection{Physico-Chemical Parameters}

Analysis of major elements in surface waters and groundwater in basement aquifers of the Eastern Senegal shows that, waters are generally low mineralized with electric conductivities (EC) ranging from 49 to 790 $\mu \mathrm{S} \cdot \mathrm{cm}^{-1}$ (Table 1) in relation with the geological nature of aquifers. Median value EC is lower $\left(48 \mu \mathrm{S} \cdot \mathrm{Cm}^{-1}\right.$ ) for Gambia River water comparing to groundwater samples. Groundwaters in Granite setting exhibit the lowest median value $\left(185 \mu \mathrm{S} \cdot \mathrm{Cm}^{-1}\right)$, followed groundwater sampled in mafic volcanic terrain $\left(213 \mu \mathrm{S} \cdot \mathrm{Cm}^{-1}\right)$ and those from schistes and volcano-sediments which median value is the highest $\left(351 \mu \mathrm{S} \cdot \mathrm{Cm}^{-1}\right)$. However it should be noted that the maximum EC was recorded at Bembou well $\left(790 \mu \mathrm{S} \cdot \mathrm{cm}^{-1}\right)$ tapping the granite rock; this high value is likely to be induced by organic pollution marked by high $\mathrm{NO}_{3}^{-}$content $\left(227.34 \mathrm{mg} \cdot \mathrm{L}^{-1}\right)$ which contributes significantly to the overall mineralization of the water. Values of $\mathrm{pH}$ are slightly acidic to circum-neutral with median values of 6.6 in granite, 6.9 in schistes and volcano-sediment, and 6.3 in mafic volcanic rocks groundwater setting while they are neutral to slightly basic with a median value of 7.5 for surface waters. This latter can be explained by degassing of $\mathrm{CO}_{2}$ in torrential surface waters [12]. However, acidic waters are encountered in wells (P3, P2 and P4) located in Sabodala village with respective values of 5.3, 5.8 and 5.5.

Surface waters showed a more oxidizing characteristic with a median value of dissolved oxygen $\left(\mathrm{O}_{2}\right)(7.09$ $\mathrm{mg} \cdot \mathrm{L}^{-1}$ ) followed by mafic volcanic rocks GW $\left(4.05 \mathrm{mg} \cdot \mathrm{L}^{-1}\right)$ while granites $\mathrm{GW}$ and schistes and volcano-sediments GW exhibit respectively median values of dissolved $\mathrm{O}_{2}$, of $3.9 \mathrm{mg} \cdot \mathrm{L}^{-1}$ and $2.5 \mathrm{mg} \cdot \mathrm{L}^{-1}$, respectively. This low content of dissolved $\mathrm{O}_{2}$ observed in schistes and volcano-sediment GW could be explained by presence of clay minerals that makes the system closed, therefore less oxidant. However Eh median values show similar trend about $50 \mathrm{mV}$ in different water groups except in mafic volcanic rocks $\mathrm{GW}$ where lowest median value is recorded $(12 \mathrm{mV})$. A relatively high Eh value $(121 \mathrm{mV})$ is observed at Sabodala River indicating a polluted environment at this level.

\subsection{Hydrochemistry of Major Ions and Geochemical Processes}

The crystalline rock environment is composed of various igneous and metamorphic rock types. Formation 


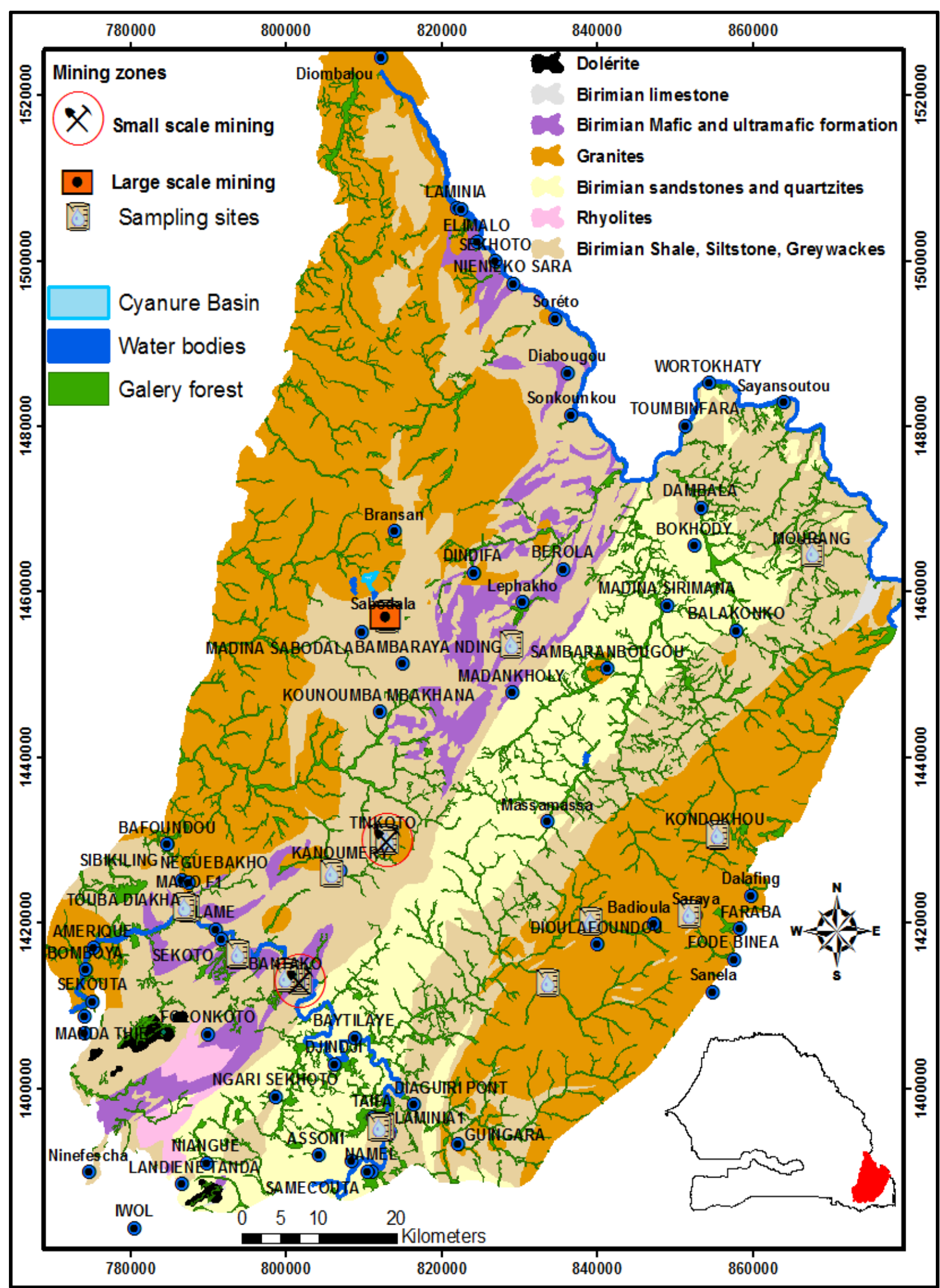

Figure 2. Hydrogeological entities and location of sampling sites [13] (modified). 
processes control their composition and physical properties. Ultramafic rocks are composed of mineral assemblages that crystallize at high temperatures than felsic rock assemblages. Table 2 gives a very brief summary of the chemical and mineralogical characteristics of few rock types in contact with fluids found in crystalline environments [14]. Mafic and ultramafic rocks tend to be composed of mineral phase rich iron-manganese-calcium silicates, whereas felsic rocks tend to contain more sodium-potassium-calcium [15]. Water/rock interaction should likely imprint chemical processes occurring in each geological formation.

Mostly, water chemistry in the study area, is characterized by $\mathrm{HCO}_{3}-\mathrm{Ca}-\mathrm{Mg}, \mathrm{HCO}_{3}$-Na water types reflecting chemical signature of waters from crystalline and cristallophyllian environments where, water mineralization is controlled by silicate weathering reactions, which produce bicarbonates, cations, silica often accompanied by an increase in $\mathrm{pH}$ [16]. Groundwaters (GW) in granite rock are characterized by alkali $(\mathrm{Na}+\mathrm{K}$ ) contents much greater (median value of $21.2 \mathrm{mg} \cdot \mathrm{L}^{-1}$ ) than those from schistes/volcano-sediments and mafic volcanic that exhibit median concentration values of $19.8 \mathrm{mg} \cdot \mathrm{L}^{-1}$ and $13.9 \mathrm{mg} \cdot \mathrm{L}^{-1}$, respectively (Table 3, Figure 3). Alkali ions enrichment in Granite GW is mainly due to K-feldspar and biotite weathering according to reactions below (Equations (3)-(5)) described by [16]. Conversely, alkaline earth $\left(\mathrm{Ca}^{2+}\right.$ and $\left.\mathrm{Mg}^{2+}\right)$ contents are much greater in schistes and volcanic-sediment GW (Figure 3) with a median concentration of $44.9 \mathrm{mg} \cdot \mathrm{L}^{-1}$ followed by mafic volcanic GW $\left(30.3 \mathrm{mg} \cdot \mathrm{L}^{-1}\right)$ then granites $\mathrm{GW}\left(16.5 \mathrm{mg} \cdot \mathrm{L}^{-1}\right)$. The Bicarbonates show the same trend with values of $143.3,73.2 \mathrm{mg} \cdot \mathrm{L}^{-1}$ for schistes/volcano-sediments mafic volcanic and granites, respectively. Enrichment of $\mathrm{Ca}^{2+}, \mathrm{Mg}^{2+}$ and $\mathrm{HCO}_{3}^{-}$ions in schistes and volcano-sediment GW probably derived from weathering of pyroxene mineral (Equation (4)) in mafic rock and carbonate minerals dissolution such as calcite and dolomite in sedimentary formations. Plagioclase weathering may also contribute to these ions contents [17] (Equation (2)). Since, plagioclase has a higher solubility and dissolution rate, it may substantially contribute to sodium and calcium in solution, therefore $\mathrm{Ca} / \mathrm{Na}$ ratio would reflect congruent dissolution of plagioclase. However, different $\mathrm{Ca} / \mathrm{Na}$ ratio to that of plagioclase found in the weathered aquifer implies other sources of Ca or a sink of $\mathrm{Na}$ [18]. Therefore, water chemistry in upper weathered aquifers evolves very differently, and can be also affected by organic pollution marked by high concentrations of $\mathrm{NO}_{3}^{-}$in the majority of sampled wells (Table 4). Nitrate

Table 1. Chemistry and mineralogy of representative rock types from crystalline rock environments (analyses normalized to $100 \%$, including $\mathrm{MnO} . \mathrm{P}_{2} \mathrm{O}_{5}$, water free; oxides are in wt.\%) [14].

\begin{tabular}{ccccc}
\hline $\begin{array}{c}\text { Type of rock parameter } \\
\text { no. of analyses }\end{array}$ & $\begin{array}{c}\text { Ultramafic (peridotite) } \\
\mathrm{n}=287\end{array}$ & $\begin{array}{c}\text { Mafic (gabbro) } \\
\mathrm{n}=1.451\end{array}$ & $\begin{array}{c}\text { Intermediate (diorite) } \\
\mathrm{n}=872\end{array}$ & $\begin{array}{c}\text { Felsic (granite) } \\
\mathrm{n}=2.485\end{array}$ \\
\hline $\mathrm{SiO}_{2}$ & 45.31 & 51.06 & 58.58 & 72.04 \\
$\mathrm{TiO}_{2}$ & 0.52 & 1.17 & 0.96 & 0.30 \\
$\mathrm{Al}_{2} \mathrm{O}_{3}$ & 4.38 & 15.91 & 16.98 & 14.42 \\
$\mathrm{Fe}_{2} \mathrm{O}_{3}$ & 4.28 & 3.10 & 2.55 & 1.22 \\
$\mathrm{FeO}$ & 7.48 & 7.76 & 5.13 & 1.68 \\
$\mathrm{MnO}$ & 0.26 & 0.12 & 0.12 & 0.05 \\
$\mathrm{MgO}$ & 31.19 & 7.68 & 3.73 & 0.71 \\
$\mathrm{CaO}$ & 5.5 & 9.88 & 6.66 & 1.82 \\
$\mathrm{Na}$ & 0.55 & 2.48 & 3.60 & 3.69 \\
$\mathrm{~K}_{2} \mathrm{O}$ & 0.3 & 0.96 & 1.81 & 4.12 \\
$\mathrm{P}_{2} \mathrm{O}_{5}$ & 0.11 & 0.24 & 0.29 & 0.12 \\
$\mathrm{Minerals}$ & Ol. Py & Py. Pl. Hb. Bi & Pl. Hb. Bi & Pl. Kspar. Bi. Qtz \\
\hline
\end{tabular}

$\mathrm{Ol}$ = olivine, $\mathrm{Py}=$ pyroxene, $\mathrm{Hb}=$ hornblende, $\mathrm{Bi}=$ biotite, $\mathrm{Pl}=$ plagioclase feldspar, $\mathrm{Kspar}=$ potassium feldspar, $\mathrm{Qtz}=$ quartz.

Table 2. Statistic of physico-chemical parameters (CE, $\mathrm{pH}, \mathrm{T}^{\circ} \mathrm{C}, \mathrm{O}_{2}$, Eh).

\begin{tabular}{|c|c|c|c|c|c|c|c|c|c|c|c|c|c|c|c|c|}
\hline \multirow[t]{2}{*}{ Type } & \multicolumn{4}{|c|}{ Granites } & \multicolumn{4}{|c|}{ Schistes and volcano-sediment } & \multicolumn{4}{|c|}{ Mafic volcanic } & \multicolumn{4}{|c|}{ Surface waters } \\
\hline & Min & Max & Median & $\mathrm{n}$ & Min & Max & Median & $\mathrm{n}$ & Min & Max & Median & $\mathrm{n}$ & Min & Max & Mediane & $\mathrm{n}$ \\
\hline $\mathrm{pH}$ & 6.5 & 7 & 6.6 & 9 & 6.5 & 7.5 & 6.9 & 6 & 5.3 & 7.4 & 6.3 & 6 & 7.09 & 7.9 & 7.5 & 5 \\
\hline $\mathrm{CE} \mu \mathrm{S} \cdot \mathrm{Cm}^{-1}$ & 49 & 790 & 185 & 9 & 129 & 724 & 351 & 6 & 59 & 701 & 213 & 6 & 47 & 292 & 48 & 5 \\
\hline $\mathrm{T}^{\circ} \mathrm{C}$ & 25.2 & 31.7 & 26.6 & 9 & 26.6 & 31 & 29.9 & 6 & 28.2 & 32.2 & 30.7 & 6 & 23.7 & 25.1 & 24.2 & 5 \\
\hline $\mathrm{O}_{2} \mathrm{mg} \cdot \mathrm{L}^{-1}$ & 3.09 & 5.5 & 3.9 & 9 & 1.5 & 5.1 & 2.5 & 6 & 1.8 & 5.6 & 4.05 & 6 & 2.5 & 14.9 & 7.09 & 5 \\
\hline Eh mV & 10.5 & 56.09 & 51 & 9 & 15.9 & 59.2 & 52.5 & 6 & 6.3 & 51 & 12.15 & 6 & 28 & 121.3 & 59.2 & 5 \\
\hline
\end{tabular}


Table 3. Statistics on major ion contents in water from different aquifer types.

\begin{tabular}{|c|c|c|c|c|c|c|c|c|c|c|c|c|c|c|c|c|}
\hline \multirow[t]{2}{*}{ Type } & \multicolumn{4}{|c|}{ Granites } & \multicolumn{4}{|c|}{$\begin{array}{c}\text { Schistes \& } \\
\text { Volcano-sediment }\end{array}$} & \multicolumn{4}{|c|}{ Mafic basic } & \multicolumn{4}{|c|}{ Surface water } \\
\hline & Min & Max & Médiane & $\mathbf{n}$ & Min & Max & Median & $\mathbf{n}$ & Min & Max & Median & $\mathbf{n}$ & Min & Max & Median & $\mathbf{n}$ \\
\hline $\mathrm{Ca}\left(\mathrm{mg} \cdot \mathrm{L}^{-1}\right)$ & 1.7 & 61.23 & 14.82 & 9 & 9.23 & 78.2 & 35.9 & 6 & 4.77 & 49.7 & 21.7 & 6 & 1.03 & 23.12 & 3.78 & 5 \\
\hline $\operatorname{Mg}\left(\mathrm{mg} \cdot \mathrm{L}^{-1}\right)$ & 1.4 & 30.8 & 3.04 & 9 & 0.88 & 25.3 & 9.03 & 6 & 2.45 & 47.5 & 8.67 & 6 & 0.33 & 9.2 & 2.3 & 5 \\
\hline $\mathrm{Na}\left(\mathrm{mg} \cdot \mathrm{L}^{-1}\right)$ & 3 & 62.7 & 18.1 & 9 & 3.7 & 34.6 & 17.7 & 6 & 1.6 & 61.9 & 12.2 & 6 & 1.1 & 20.6 & 2.6 & 5 \\
\hline $\mathrm{Si}\left(\mathrm{mg} \cdot \mathrm{L}^{-1}\right)$ & 7.5 & 32 & 29 & 9 & 10.3 & 33.7 & 23 & 6 & 6.2 & 19.1 & 6.8 & 6 & 4.8 & 10.4 & 5.2 & 5 \\
\hline $\mathrm{K}\left(\mathrm{mg} \cdot \mathrm{L}^{-1}\right)$ & 0.3 & 21.4 & 2.3 & 9 & 1.8 & 9.1 & 2.1 & 6 & 0.2 & 4.7 & 1.7 & 6 & 0.2 & 3.7 & 3.1 & 5 \\
\hline $\mathrm{HCO}_{3}\left(\mathrm{mg} \cdot \mathrm{L}^{-1}\right)$ & 18.3 & 115.9 & 73.2 & 9 & 61 & 366 & 143.3 & 6 & 6.1 & 280.6 & 73.2 & 6 & 24.4 & 164.7 & 24.4 & 5 \\
\hline $\mathrm{Cl}\left(\mathrm{mg} \cdot \mathrm{L}^{-1}\right)$ & 2.1 & 63.7 & 6.3 & 9 & 2.6 & 37.6 & 8.2 & 6 & 2.2 & 55.6 & 8.2 & 6 & 2.05 & 7.3 & 2.1 & 5 \\
\hline $\mathrm{SO}_{4}\left(\mathrm{mg} \cdot \mathrm{L}^{-1}\right)$ & 0.3 & 113.5 & 5.1 & 9 & 0.4 & 21.7 & 5.04 & 6 & 0.5 & 11.34 & 1.26 & 6 & 0.3 & 1.6 & 0.4 & 5 \\
\hline $\mathrm{NO}_{3}\left(\mathrm{mg} \cdot \mathrm{L}^{-1}\right)$ & 0 & 224.3 & 2.09 & 9 & 0.29 & 43.1 & 6.1 & 6 & 0 & 277.5 & 23.7 & 6 & 0 & 0.47 & 0 & 5 \\
\hline
\end{tabular}

Table 4. Chemical composition of major elements in $\left[\mathrm{mg} \cdot \mathrm{L}^{-1}\right]$.

\begin{tabular}{|c|c|c|c|c|c|c|c|c|c|c|c|c|c|c|c|}
\hline Id & No. & Type & $\mathbf{T}^{\circ} \mathbf{C}$ & pH & Eh & $\mathbf{O}_{2}$ & Ca & Mg & $\mathrm{Na}$ & $\mathbf{K}$ & $\mathrm{HCO}_{3}$ & Cl & $\mathrm{SO}_{4}$ & $\mathrm{NO}_{3}$ & Balance \\
\hline SrP & 1 & Gr & 25.9 & 6.7 & 46 & 5.5 & 41.4 & 11.3 & 44.1 & 4.5 & 91.5 & 53.5 & 16.5 & 106.1 & -0.2 \\
\hline BemP & 2 & Gr & 27.6 & 6.8 & 56 & 3.9 & 61.2 & 30.8 & 52.6 & 2.4 & 115.9 & 63.7 & 27.3 & 224.3 & 0.4 \\
\hline KhkF & 3 & Gr & 26.6 & 6.6 & 48.3 & 4.9 & 37.2 & 2.1 & 13.7 & 21.4 & 73.2 & 31.1 & 113.5 & 2.1 & -1.1 \\
\hline KhkP & 4 & Gr & 26.6 & 6.6 & 48.3 & 4.9 & 21.4 & 8.8 & 62.7 & 5.8 & 24.4 & 41.4 & 13.5 & 180.4 & -0.8 \\
\hline TinP4 & 5 & Gr & 31.0 & 6.8 & 10.5 & 3.1 & 7.6 & 3.1 & 12.4 & 1.7 & 73.2 & 2.2 & 0.8 & 0.2 & -2.4 \\
\hline PonP & 6 & Gr & 26.5 & 7.0 & 56.1 & 5.2 & 14.8 & 1.7 & 18.1 & 1.2 & 73.2 & 6.3 & 4.9 & 17.8 & -1.9 \\
\hline TinP2 & 7 & Gr & 26.0 & 6.7 & 51 & 3.5 & 13.4 & 3.04 & 19.3 & 1.9 & 103.7 & 3.2 & 1.6 & 2.0 & -1.3 \\
\hline TinP1 & 8 & Gr & 25.3 & 6.5 & 56.1 & 3.4 & 1.7 & 1.4 & 4.6 & 0.3 & 18.3 & 2.6 & 5.2 & 0.0 & -8.4 \\
\hline TinF1 & 9 & Gr & 31.8 & 6.6 & 54.8 & 3.4 & 14.1 & 2.3 & 3 & 11.8 & 91.5 & 2.1 & 0.0 & 0.4 & -1.8 \\
\hline KosP & 10 & $\mathrm{~S} \& \mathrm{Vs}$ & 26.6 & 6.6 & 53.3 & 4.3 & 29.5 & 11.2 & 34.7 & 1.9 & 122.0 & 27.5 & 21.7 & 42.2 & 0.6 \\
\hline KanF & 11 & $\mathrm{~S} \& \mathrm{Vs}$ & 28.2 & 7.2 & 51.8 & 2.5 & 57.5 & 23.4 & 17.4 & 2.3 & 329.4 & 2.6 & 1.3 & 0.3 & 0.9 \\
\hline MouF & 12 & $\mathrm{~S} \& \mathrm{Vs}$ & 30.9 & 6.6 & 59.3 & 2.5 & 9.2 & 0.8 & 3.7 & 9.1 & 61.0 & 3.6 & 6.1 & 0.4 & -1.1 \\
\hline SamP & 13 & $\mathrm{~S} \& \mathrm{Vs}$ & 29.8 & 6.7 & 56.1 & 5.2 & 26.5 & 5.2 & 18.2 & 1.8 & 97.6 & 9.3 & 5.8 & 43.1 & -1.5 \\
\hline MouP & 14 & $\mathrm{~S} \& \mathrm{Vs}$ & 30.0 & 7.5 & 15.9 & 1.5 & 42.3 & 6.8 & 9.2 & 1.9 & 164.7 & 7.1 & 8.3 & 0.4 & 0.7 \\
\hline BanF & 15 & $\mathrm{~S} \& \mathrm{Vs}$ & 31.0 & 7.3 & 49 & 2.4 & 78.2 & 25.4 & 30.1 & 2.8 & 366 & 37.6 & 4.2 & 6.1 & 0.9 \\
\hline SbP4 & 16 & V.B & 28.3 & 5.5 & 6.3 & 5.7 & 7.8 & 5.4 & 22.5 & 2.6 & 6.1 & 13.3 & 1.1 & 88.7 & -1.1 \\
\hline MakF & 17 & V.B & 32.3 & 7.4 & 22.1 & 1.8 & 49.7 & 47.6 & 14.02 & 1.6 & 280.6 & 49.6 & 11.3 & 47.1 & 0.4 \\
\hline SbP & 18 & V.B & 29.3 & 7.2 & 13.8 & 4 & 25.3 & 8.9 & 2.1 & 0.5 & 122 & 2.2 & 2.8 & 0.3 & -0.5 \\
\hline SbP2 & 19 & V.B & 31.8 & 5.8 & 51 & 4.1 & 4.7 & 2.4 & 1.6 & 0.3 & 24.4 & 3.3 & 1.1 & 0 & 0.1 \\
\hline SbP3 & 20 & V.B & 29.8 & 5.3 & 10.5 & 5.5 & 33.6 & 20.9 & 61.9 & 4.7 & 6.1 & 55.6 & 1.3 & 277.5 & 0.3 \\
\hline TomF & 21 & V.B & 31.8 & 6.8 & 6.3 & 2.9 & 18.2 & 8.4 & 10.4 & 1.7 & 128.1 & 2.2 & 0.5 & 0.4 & -1.9 \\
\hline GamA & 22 & E.S & 24.3 & 7.5 & 121.3 & 7 & 1.09 & 0.4 & 2.6 & 3.7 & 24.4 & 2.0 & 0.0 & 0.4 & -0.9 \\
\hline SbR & 23 & E.S & 23.8 & 7.1 & 51.8 & 14.9 & 23.1 & 9.3 & 20.7 & 3.1 & 164.7 & 7.3 & 1.6 & 0.5 & -0.8 \\
\hline GamV & 24 & E.S & 24.3 & 7.6 & 59.3 & 7.1 & 3.7 & 2.5 & 2.7 & 0.5 & 30.5 & 2.3 & 0.8 & 0 & -4.2 \\
\hline GamS & 25 & E.S & 24.1 & 7.6 & 101 & 2.6 & 4.1 & 2.4 & 1.1 & 0.2 & 24.4 & 2.1 & 0.3 & 0 & -1.2 \\
\hline GamM & 26 & E.S & 25.1 & 7.9 & 28 & 7.1 & 1.03 & 0.3 & 2.6 & 3.7 & 24.4 & 2.1 & 0.0 & 0.4 & -1.5 \\
\hline
\end{tabular}



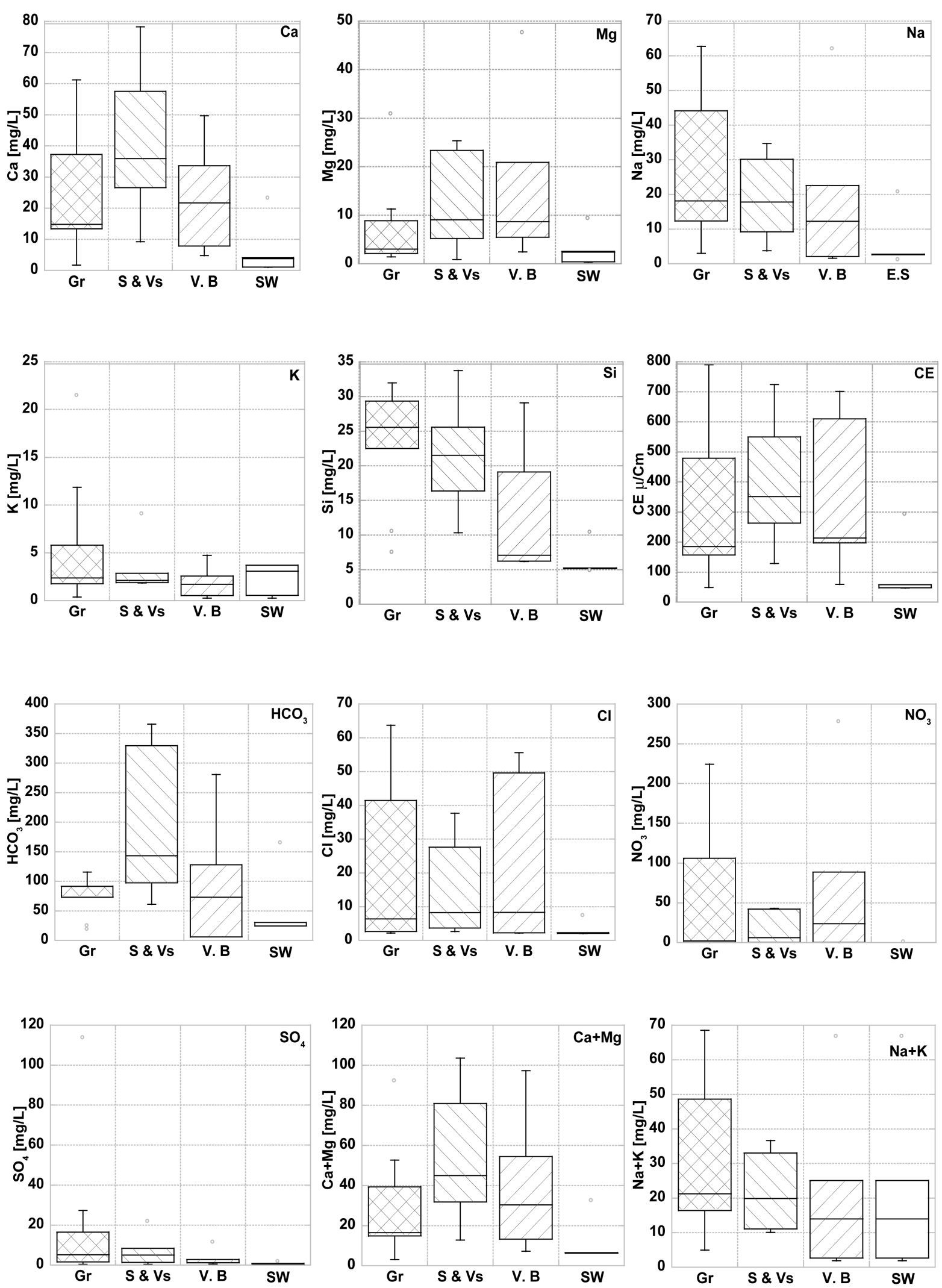

Figure 3. Boxplot of major ions composition in water from different sampled reservoirs (January 2011). (Gr. = Granites; S \& Vs. = Schistes and Volcano-sediment; V B. = mafic basic; SW. = surface waters). 
concentrations in most boreholes are lower and below the permissible guideline value for drinking water (50 $\mathrm{mg} \cdot \mathrm{L}^{-1}$ ) at the exeption of Mako borehole (MakF) which content is relatively higher $\left(47.1 \mathrm{mg} \cdot \mathrm{L}^{-1}\right)$. Thus, chemical signatures of boreholes' waters reflect characteristics of the geological nature of the aquifer reservoir since these latters are not affected by pollution [9].

Surface water samples collected from the Gambia River at various stations exhibit very low EC values, ranging between 47 and $58 \mu \mathrm{S} \cdot \mathrm{cm}^{-1}$, and much higher $\left(292 \mu \mathrm{S} \cdot \mathrm{cm}^{-1}\right)$ at the Sabodala stream. This latter may involve an additional contribution of elements from various sources as well as evaporation process since flow is low in the stream.

\subsection{Equations}

(1) (Albite) sodic plagioclase Kaolinite

$2 \mathrm{Na}\left(\mathrm{AlSi}_{3}\right) \mathrm{O}_{8}+2 \mathrm{H}^{+}+9 \mathrm{H}_{2} \mathrm{O} \rightarrow \mathrm{Al}_{2} \mathrm{Si}_{2} \mathrm{O}_{5}(\mathrm{OH})_{4}+2 \mathrm{Na}^{+}+4 \mathrm{H}_{4} \mathrm{SiO}_{4}$

(2) (Anorthite) calcic plagioclase

$\mathrm{Ca}\left(\mathrm{Al}_{2} \mathrm{Si}_{2}\right) \mathrm{O}_{8}+2 \mathrm{H}^{+}+\mathrm{H}_{2} \mathrm{O} \rightarrow \mathrm{Al}_{2} \mathrm{Si}_{2} \mathrm{O}_{5}(\mathrm{OH})_{4}+\mathrm{Ca}^{2+}$

(3) (Microcline) K-feldspar

$2 \mathrm{~K}\left(\mathrm{AlSi}_{3}\right) \mathrm{O}_{8}+2 \mathrm{H}^{+}+9 \mathrm{H}_{2} \mathrm{O} \rightarrow \mathrm{Al}_{2} \mathrm{Si}_{2} \mathrm{O}_{5}(\mathrm{OH})_{4}+2 \mathrm{~K}^{+}+4 \mathrm{H}_{4} \mathrm{SiO}_{4}$

(4) (Augite) Pyroxene

$\left(\mathrm{Mg}_{0.7} \mathrm{CaAl}_{0.3}\right)\left(\mathrm{Al}_{0.3} \mathrm{Si}_{1.7}\right) \mathrm{O}_{6}+3.4 \mathrm{H}^{+}+1.1 \mathrm{H}_{2} \mathrm{O} \rightarrow 0.3 \mathrm{Al}_{2} \mathrm{Si}_{2} \mathrm{O}_{5}(\mathrm{OH})_{4}+\mathrm{Ca}^{2+}+0.7 \mathrm{Mg}^{2+}+1.1 \mathrm{H}_{4} \mathrm{SiO}_{4}$

(5) (Biotite) Mica

$$
2 \mathrm{~K}\left(\mathrm{Mg}_{2} \mathrm{Fe}\right)\left(\mathrm{AlSi}_{3}\right) \mathrm{O}_{10}(\mathrm{OH})_{2}+10 \mathrm{H}^{+}+0.5 \mathrm{O}_{2}+7 \mathrm{H}_{2} \mathrm{O} \rightarrow \mathrm{Al}_{2} \mathrm{Si}_{2} \mathrm{O}_{5}(\mathrm{OH})_{4}+2 \mathrm{~K}^{+}+4 \mathrm{Mg}^{2+}+2 \mathrm{Fe}(\mathrm{OH})_{3}+4 \mathrm{H}_{4} \mathrm{SiO}_{4}
$$

[16]

Use of statistical analysis software $\mathrm{R}$ has allowed to apply principal components analysis (PCA) and hierarchical cluster analysis (HCA) on major elements $\left(\mathrm{Ca}^{2+}, \mathrm{Mg}^{2+}, \mathrm{Na}^{+}, \mathrm{K}^{+}, \mathrm{HCO}_{3}^{-}, \mathrm{Cl}^{-}, \mathrm{SO}_{4}^{2-}, \mathrm{NO}_{3}^{-}, \mathrm{Si}_{4}^{+}\right)$. The advantage of PCA is that rather than examining two variables at a time in an $\mathrm{x}$ vs. $\mathrm{y}$ plot or perhaps 3 variables in a 3D plot (x, y and $\mathrm{z}$ ), all the variables from a data set can be examined simultaneously. Mathematically there are no limits when calculating more than 3 dimensions. In PCA, a set of interrelated variables is mathematically transformed into a new co-ordinate system on which the axis (principal components) are linear combinations of the original variables and are mutually non-correlated. The newly transformed variables account for the same information or variance as the original variables do. The only difference is that the first axis accounts for as much as possible the variance. The second axis accounts for the remaining variance while being non-correlated with the first axis and so forth. The variables and the axis are weighted in proportion to the amount of the total variance that they describe [19]. Often the first two principal components generally describe most of the information in the data set [20]. PCA results (Figure 5(a), Figure 5(b)) show that most of ions contributes significantly to the factorial axis F1. Contribution of each element on this axis depends of the radius assigned to the element on the correlation circle. Thus, $\mathrm{Cl}^{-}, \mathrm{Ca}^{2+}, \mathrm{Mg}^{2+}, \mathrm{Na}^{+}, \mathrm{Si}_{4}^{+}$and $\mathrm{NO}_{3}^{-}$ions contribute significantly to the first principal component (F1), which represents $32 \%$ of the total variance in the data. The $\mathrm{F} 1$ axis represents all ions participating in mineralization of waters. Nevertheless, at the second principal component (F2) which represents $20 \%$ of the total variance, a positive correlation is shown between $\mathrm{HCO}_{3}^{-}, \mathrm{Ca}^{2+}, \mathrm{Mg}^{2+}$ and $\mathrm{Si}_{4}^{+}$, which suggests a common natural origin of these elements which is though, to be mainly silicates hydrolysis. $\mathrm{HCO}_{3}^{-}$enrichment in waters is accompanied by an increase of $\mathrm{Si}_{4}^{+}$followed by $\mathrm{Ca}^{2+}, \mathrm{Mg}^{2+}$ ions approximately to an equal proportion. This group characterized by Ca-Mg- $\mathrm{HCO}_{3}$ water type contrasts with the $\mathrm{Na}-\mathrm{NO}_{3}-\mathrm{Cl}$ group (Figure 4(a)) that indicates an anthropogenic source of water mineralization with high $\mathrm{NO}_{3}$ contents. Water contamination by nitrates accompanied by an increase in $\mathrm{Cl}^{-}$concentrations is therefore, more likely related to organic matters. F2 axis indicates that alkaline earth $\left(\mathrm{Ca}^{2+}, \mathrm{Mg}^{2+}\right)$ are anti-correlated with alkali $\left(\mathrm{Na}^{+}\right.$, $\mathrm{K}^{+}$); the first being characteristic of schistes volcano-sediment and mafic-volcanic rocks GW and the latest characterize granites GW (Figure 5(b)).

Overall, PCA shows three main sources of water mineralization (Figure 4(a)). The distribution of clusters based on the first three PCA (Figure 6) shows that: 


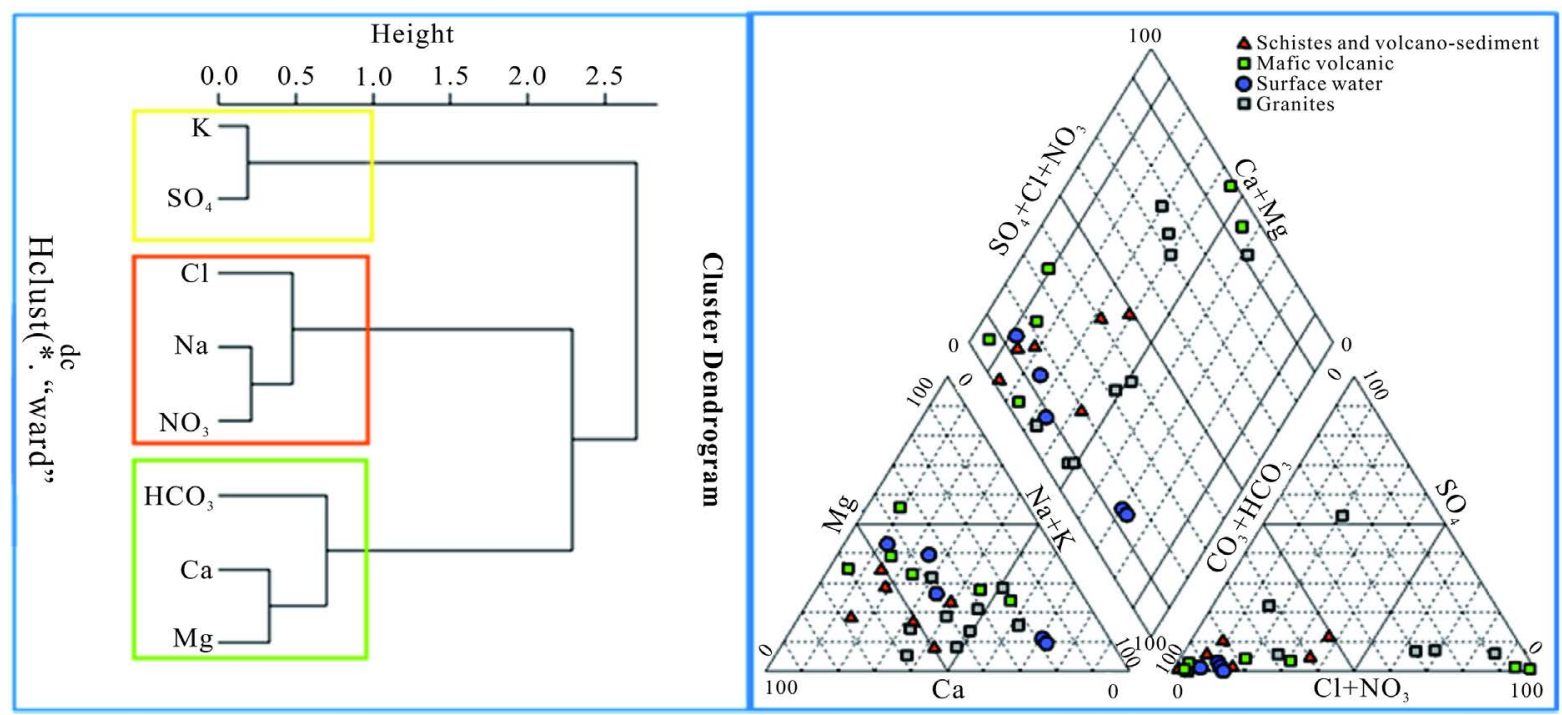

Figure 4. HAC of different water groups and piper diagram showing different water types.

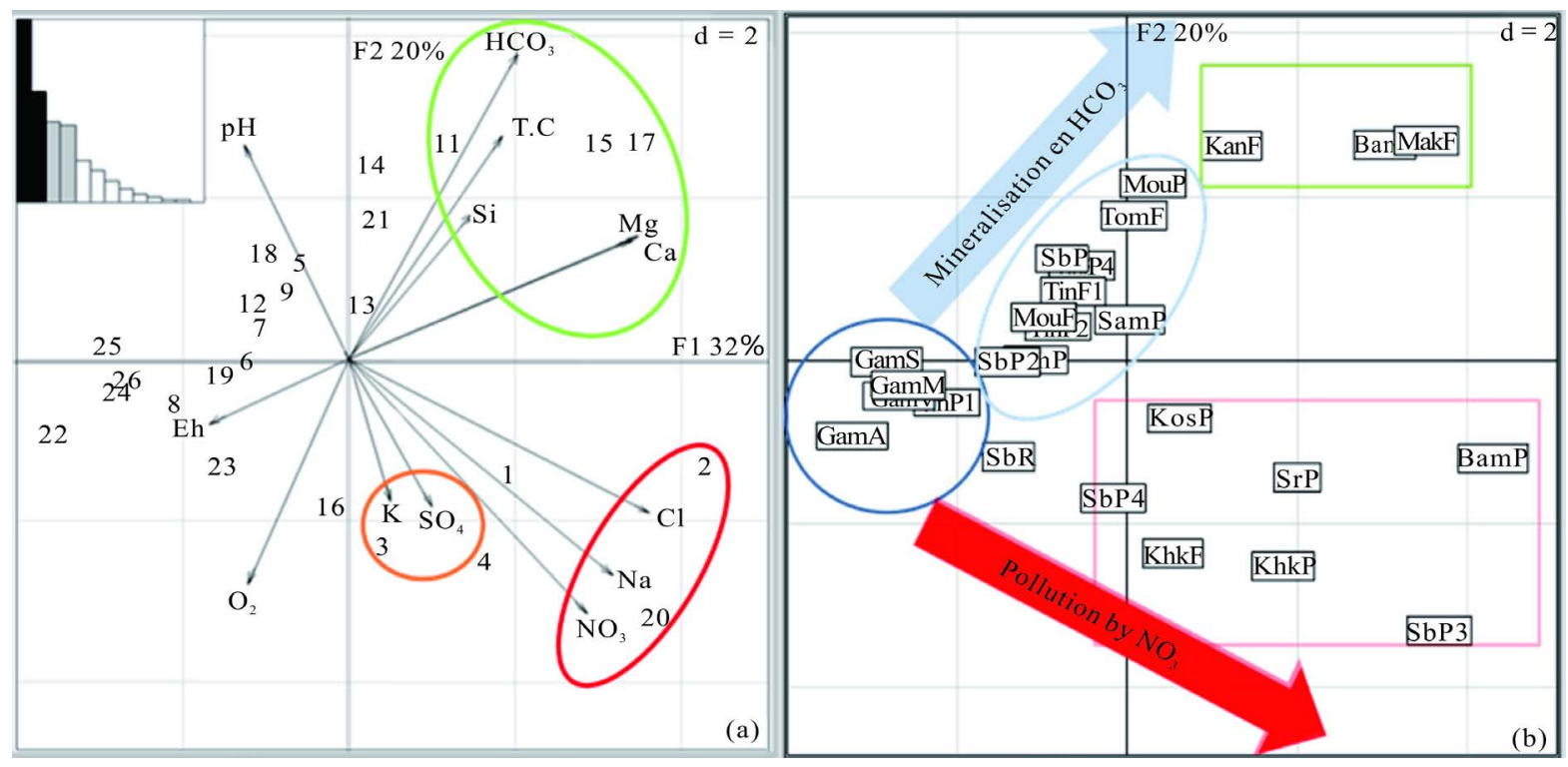

Figure 5. Principal components analyse (PCA) of major ions $\left(\mathrm{Ca}^{2+}, \mathrm{Mg}^{2+}, \mathrm{Na}^{+}, \mathrm{K}^{+}, \mathrm{HCO}_{3}^{-}, \mathrm{Cl}^{-}, \mathrm{NO}_{3}^{-}, \mathrm{SO}_{4}^{2-}, \mathrm{Si}_{4}^{+}\right)$.

Clusters 1, 3 and 4 define unpolluted water type (Ca-Mg- $\left.\mathrm{HCO}_{3}\right)$ and are essentially encountered in surface waters and water samples from boreholes. Low mineralized waters, uncontaminated with a Ca- $\mathrm{Mg}-\mathrm{HCO}_{3}$ water type derived from silicate weathering characterize these groups, which occur boreholes tapping lower fractured aquifers;

Clusters 2 and 6 which water types are $\mathrm{Ca}-\mathrm{Mg}-\mathrm{NO}_{3}-\mathrm{Cl}$ and $\mathrm{Na}-\mathrm{NO}_{3}-\mathrm{Cl}$ water types are mostly polluted and of poor quality. They are represented by dug wells tapping the upper weathered aquifer (Figure 5(b)) that are often affected by organic pollution with high nitrate contents exceeding the WHO standards guide for drinking water (50 mg. $\left.\mathrm{l}^{-1}\right)$;

Finally the cluster 5 with relatively higher $\mathrm{K}^{+}$and $\mathrm{SO}_{4}^{2-}$ contents is encountered in the Saraya granite. These relatively high concentrations are probably related water/granites interaction which are rich in biotite and K-feldspar. In fact, as the Saraya granites bear some sulfides minerals ( $\mathrm{Zn}$ and $\mathrm{Pb}$ ), enrichments of $\mathrm{SO}_{4}^{2-}, \mathrm{Zn}^{2+}$ and $\mathrm{Pb}^{2+}$ at Khodonkhou are likely to derive from dissolution of sulfides minerals. 


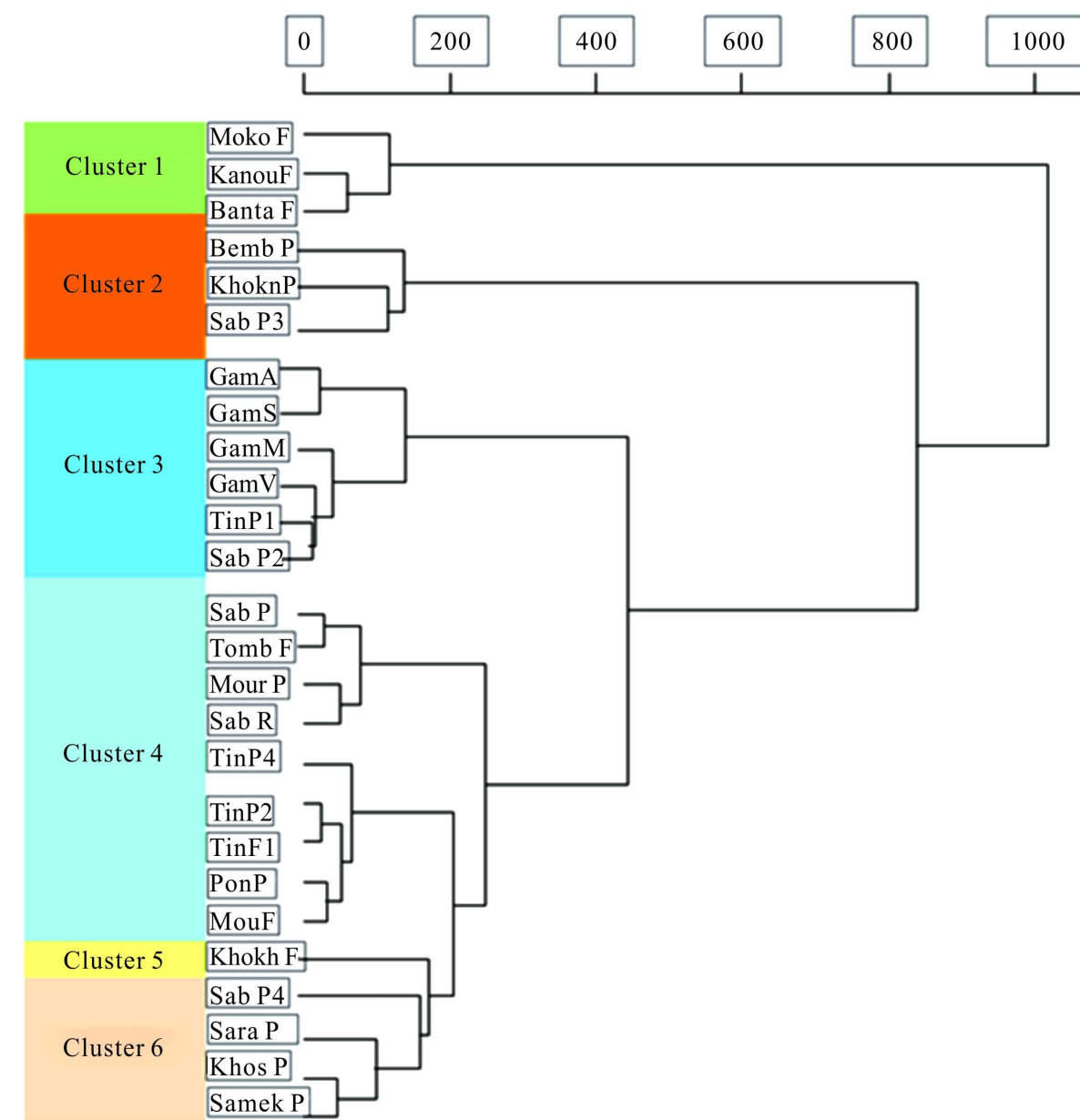

Figure 6. HAC of different water groups from different reservoirs taking into account their composition of major ions.

\subsection{Hydrochemistry of Trace Elements and Geochemical Processes}

Trace elements are natural components of the earth's crust, which contents are mostly less than $1 \mathrm{~g} \cdot \mathrm{kg}^{-1}$ in rocks. In the upper continental crust, they constitute $0.6 \%$ of the total mass, while 11 major elements represent $99.4 \%$ [21]. However, concentrations in water depend both on minerals weathering and their mobility. Thus, aluminum, iron and titanium are among the major components of the Earth's crust but are present at trace levels in waters.

In surface waters, concentrations of trace elements are below $1 \mathrm{mg} \cdot \mathrm{L}^{-1}$ [21]. They can be strongly influenced by human activities especially in traditional and industrial gold mining due to ore treatment. According to INERIS [22], in mining areas, trace metals concentrations are locally high. Although, these elements are so less mobile due to that they are part of the crystal structure of minerals, the risk of migration results mainly from sulfides oxidation in galleries or tailings present on surface. Acidification of waters that results to this process leads to dissolved trace element (called acid rock drainage in the case of a pit water) that could be transported to another site. In the study area, trace elements composition of waters is highly variable depending on aquifer types (Table 5, Figure 7). Enrichment of trace element contents in water is especially noted in the gold mining areas where most important trace elements ( $\mathrm{Al}, \mathrm{Ni}, \mathrm{Mn}, \mathrm{Cr}$ and $\mathrm{Co}$ ) that affect water quality occur above background level. Statistical analysis shows that $\mathrm{Al}$ contents are relatively high in eastern Senegal groundwaters, its mean concentration is about $257 \mu \mathrm{g} \cdot \mathrm{L}^{-1}$ in Granite and the maximum value $\left(700 \mu \mathrm{g} \cdot \mathrm{L}^{-1}\right)$ is recorded at Tinkoto P4 well where traditional gold mining operates at the village. In the schistes and volcano-sediments setting, the median $\mathrm{Al}$ content is $55 \mu \mathrm{g} \cdot \mathrm{L}^{-1}$ and the maximum concentration is observed at Khossanto wells $\left(166 \mu \mathrm{g} \cdot \mathrm{L}^{-1}\right)$. In mafic volcanic GW median Al content is $104.5 \mu \mathrm{g} \cdot \mathrm{L}^{-1}$ and the maximum content $\left(813 \mu \mathrm{g} \cdot \mathrm{L}^{-1}\right.$ ) encountered at P3 Sabodala. Finally in surface water, $\mathrm{Al}$ is present in weak quantities with a median concentration of $98 \mu \mathrm{g} \cdot \mathrm{L}^{-1}$, 

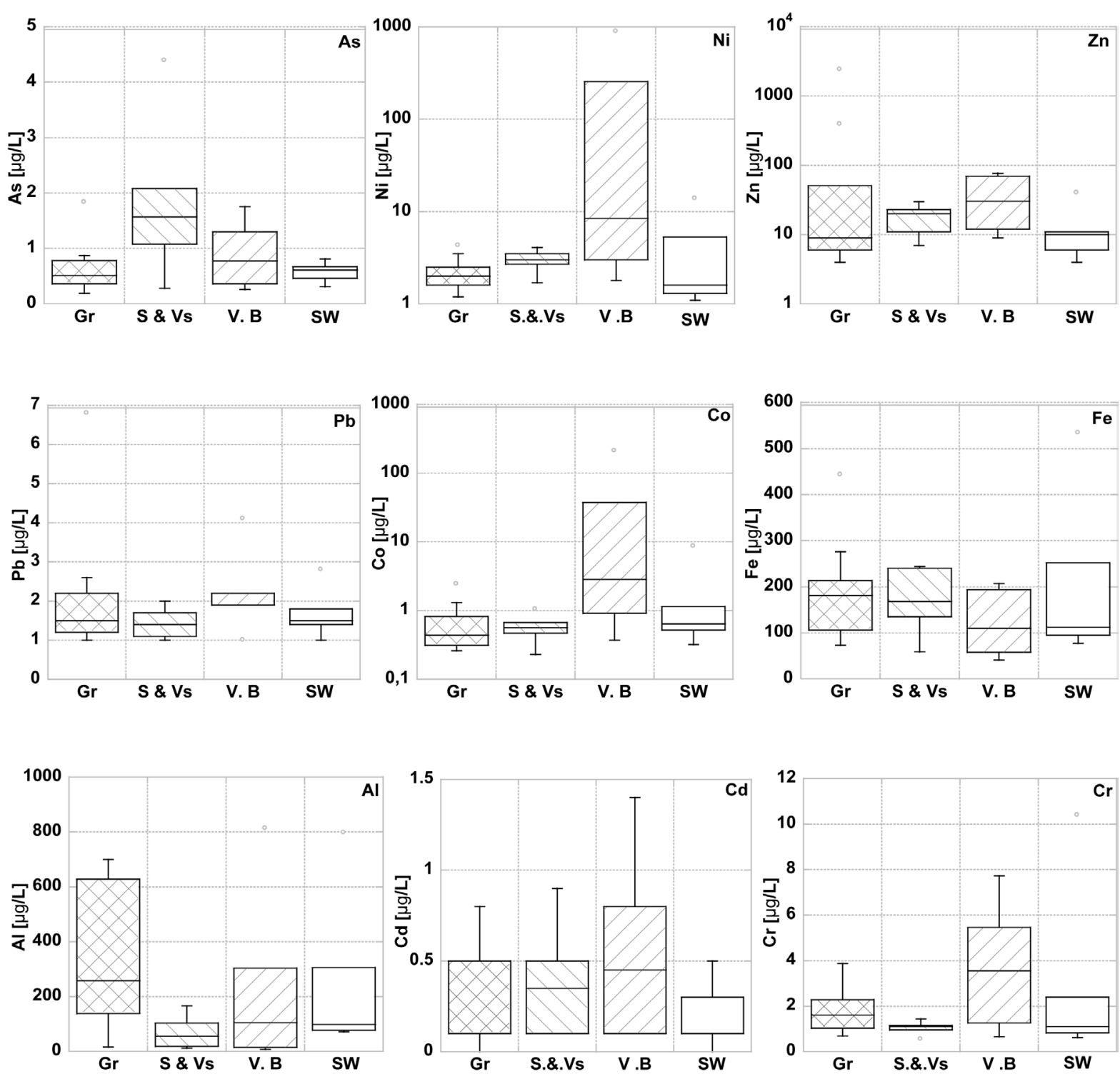

Figure 7. Boxplot of trace elements in different sampled reservoirs (Gr. = Granites; S \& Vs. = Schistes and Volcano-sediments; V B. = mafic basic; SW. = surface waters).

the maximum Al concentration is recorded at Sabodala River. However, at Bantako on the Gambia River downstream of the ore washing site $\mathrm{Al}$ content is relatively high $306 \mu \mathrm{g} \cdot \mathrm{L}^{-1}$. These relatively high Al contents in different sampled reservoirs types are mainly related to gold mining activities that enrich waters by washing the ore crushed that consequently, facilitates the release and solubilization of ions in waters. $\mathrm{Ni}$ is present at low contents in waters from different reservoirs (Table 6) except in mafic rocks and particularly at Sabodala village where the maximum concentration is observed in Sabodala well P3 $\left(890.2 \mu \mathrm{g} \cdot \mathrm{L}^{-1}\right)$. For the four wells sampled at Sabodala village, both sabP4 and sabP3 have Ni contents that exceed the standard for drinking water $\left(20 \mu \mathrm{g} \cdot \mathrm{L}^{-1}\right)$ [23] [24]. On other groundwater groups, Nikel is present at relatively low content with the median values below standard which are respectively $2 \mu \mathrm{g} \cdot \mathrm{L}^{-1}$ in granitic GW $3 \mu \mathrm{g} \cdot \mathrm{L}^{-1}, 8.45 \mu \mathrm{g} \cdot \mathrm{L}^{-1}$ in schistes and volcano-sediments GW; $1.6 \mu \mathrm{g} \cdot \mathrm{L}^{-1}$ in surface waters. These high contents of Ni observed at Sabodala could be related to industrial mining activity in the area. When comparing with $\mathrm{Mn}$ and $\mathrm{Cr}$, relatively high concentrations are encountered only at the Sabodala River with respective concentrations of $1107 \mu \mathrm{g} \cdot \mathrm{L}^{-1}$ and $10.38 \mu \mathrm{g} \cdot \mathrm{L}^{-1}$ for each of these elements. Mn was also found at Sabodala P3 with a content of $643 \mu \mathrm{g} \cdot \mathrm{L}^{-1}$ exceeding the WHO standard for drinking water $\left(500 \mu \mathrm{g} \cdot \mathrm{L}^{-1}\right)$ which always confirms impact of mining activities at this site. The other elements 
Table 5. Chemical composition of waters in trace elements $\left[\mu \mathrm{g} \cdot \mathrm{L}^{-1}\right]$ and standard deviation in \% relative on measures repeatability.

\begin{tabular}{|c|c|c|c|c|c|c|c|c|c|c|c|c|c|c|c|c|c|c|c|c|c|}
\hline Id & Tyре & $\mathrm{Cr}$ & SD\% & Mn & SD \% & $\mathbf{N i}$ & SD\% & As & SD\% & Cd & SD\% & $\mathbf{P b}$ & SD\% & $\mathrm{Fe}$ & SD\% & Co & SD\% & Al & SD\% & Zn & SD\% \\
\hline SrP & $\mathrm{Gr}$ & 1.03 & 47 & 16 & 0 & 1.6 & 25 & 0.51 & 6.8 & 0.1 & 4.0 & 1.1 & 1.2 & 181 & 07 & 0.26 & 3.1 & 351 & 1.4 & 9 & 1.9 \\
\hline BemP & $\mathrm{Gr}$ & 0.91 & 3.2 & 55 & 0.7 & 4.3 & 0.9 & 0.36 & 6.2 & 0.1 & 4.6 & 1.5 & 1.1 & 213 & 0.6 & 0.44 & 0.9 & 88 & 0.8 & 51 & 0.3 \\
\hline KhkF & $\mathrm{Gr}$ & 0.69 & 2.7 & 5 & 0.6 & 1.2 & 2.5 & 0.26 & 8.5 & 0.0 & 6.9 & 1.3 & 1.6 & 84 & 0.4 & 0.34 & 1.8 & 165 & 2.0 & 4 & 2.6 \\
\hline KhkP & $\mathrm{Gr}$ & 1.61 & 2.2 & 66 & 1.0 & 2.5 & 1.2 & 0.48 & 6.4 & 0.7 & 5.7 & 6.8 & 0.8 & 443 & 0.9 & 0.82 & 2.2 & 138 & 1.1 & 2393 & 0.9 \\
\hline TinP4 & $\mathrm{Gr}$ & 2.67 & 11.0 & 120 & 10.0 & 3.5 & 11.0 & 1.83 & 11.2 & 0.1 & 10.3 & 2.6 & 10.6 & 276 & 0.7 & 2.41 & 10.5 & 628 & 10.2 & 17 & 10.0 \\
\hline PonP & $\mathrm{Gr}$ & 1.10 & 6.4 & 9 & 6.4 & 1.6 & 6.2 & 0.19 & 10.1 & 0.1 & 8.6 & 1.0 & 6.0 & 211 & 0.4 & 0.30 & 7.8 & 645 & 6.2 & 4 & 7.1 \\
\hline TinP2 & $\mathrm{Gr}$ & 1.79 & 3.2 & 20 & 0.8 & 2.0 & 2.4 & 0.78 & 6.1 & 0.1 & 43.7 & 1.2 & 3.1 & 119 & 0.4 & 0.52 & 7.2 & 257 & 0.6 & 6 & 2.1 \\
\hline TinP1 & $\mathrm{Gr}$ & 3.87 & 14.6 & 36 & 12.3 & 2.0 & 17.5 & 0.87 & 25.1 & 0.5 & 36.9 & 2.2 & 16.5 & 106 & 0.9 & 1.31 & 19.2 & 700 & 12.2 & 6 & 14.0 \\
\hline TinF1 & $\mathrm{Gr}$ & 2.28 & 2.5 & 11 & 0.4 & 1.7 & 1.9 & 0.65 & 3.5 & 0.8 & 1.2 & 2.0 & 1.3 & 73 & 0.3 & 0.31 & 5.1 & 16 & 0.8 & 393 & 0.6 \\
\hline KosP & $\mathrm{S} \& \mathrm{Vs}$ & 1.10 & 1.4 & 18 & 0.3 & 3.1 & 1.0 & 0.28 & 4.7 & 0.1 & 7.8 & 1.3 & 1.0 & 135 & 2.0 & 0.49 & 0.9 & 166 & 0.4 & 7 & 2.4 \\
\hline KanF & $\mathrm{S} \& \mathrm{Vs}$ & 0.54 & 7.7 & 128 & 0.6 & 1.7 & 1.7 & 2.08 & 2.8 & 0.2 & 19.9 & 1.1 & 3.4 & 244 & 0.4 & 0.47 & 6.0 & 12 & 1.2 & 30 & 0.8 \\
\hline MouF & $\mathrm{S} \& \mathrm{Vs}$ & 0.95 & 10 & 2 & 0 & 2.9 & 07 & 1.08 & 1.0 & 0.1 & 13.0 & 1.0 & 1.6 & 59 & 1.1 & 0.23 & 5.4 & 104 & 0.5 & 23 & 0.2 \\
\hline SamP & $\mathrm{S} \& \mathrm{Vs}$ & 1.15 & 8.1 & 18 & 3.3 & 2.7 & 4.8 & 1.31 & 6.3 & 0.5 & 10.6 & 2.0 & 4.8 & 240 & 0.7 & 0.63 & 10.4 & 30 & 3.5 & 19 & 3.1 \\
\hline MouP & $\mathrm{S} \& \mathrm{Vs}$ & 1.10 & 7.5 & 33 & 5.6 & 4.1 & 6.1 & 4.39 & 6.6 & 0.5 & 6.5 & 1.5 & 4.4 & 143 & 0.6 & 0.67 & 5.0 & 80 & 5.9 & 11 & 6.2 \\
\hline BanF & $\mathrm{S} \& \mathrm{Vs}$ & 1.43 & 12.5 & 166 & 32.3 & 3.5 & 22.5 & 1.83 & 23.7 & 0.9 & 14.4 & 1.7 & 19.1 & 193 & 17.9 & 1.04 & 12.0 & 18 & 12.3 & 21 & 81.5 \\
\hline SbP4 & V B & 1.26 & 1.7 & 140 & 0.8 & 255.9 & 0.6 & 0.26 & 5.3 & 0.1 & 7.0 & 1.9 & 1.7 & 41 & 0.5 & 37.52 & 1.2 & 114 & 0.4 & 70 & 0.8 \\
\hline MakF & V B & 0.65 & 6.0 & 148 & 1.6 & 1.8 & 1.0 & 1.30 & 2.2 & 0.1 & 2.4 & 1.0 & 1.8 & 194 & 0.7 & 0.37 & 2.8 & 14 & 1.7 & 29 & 1.9 \\
\hline SbP & V B & 5.46 & 12.9 & 46 & 14.8 & 3.0 & 11.9 & 0.36 & 21.9 & 0.3 & 32.6 & 1.9 & 10.4 & 159 & 0. & 0. & .3 & 303 & 14.7 & 12 & 15.5 \\
\hline SbP2 & V B & 7.72 & 2.0 & 97 & 1.2 & 13.4 & 0.9 & 0.52 & 9.2 & 0.6 & 5.7 & 2.2 & 1.6 & 60 & 0.3 & 4.73 & 1.5 & 95 & 0.7 & 32 & 0.9 \\
\hline SbP3 & V B & 5.32 & 1.6 & 643 & 0.4 & 890.2 & 0.3 & 1.75 & 3.5 & 1.4 & 5.8 & 4.1 & 1.2 & 207 & 1.2 & 210.19 & 0.4 & 813 & 0.3 & 77 & 0.8 \\
\hline TomF & V B & 1.78 & 0.8 & 39 & 1.8 & 3.5 & 3.8 & 1.03 & 3.8 & 0.8 & 5.1 & 1.9 & 2.7 & 58 & 2.1 & 0.91 & 6.7 & 7 & 1.1 & 9 & 1.0 \\
\hline GamA & SW & 0.61 & 4.1 & 23 & 1.3 & 1.6 & 1.2 & 0.31 & 7.0 & 0.0 & 11.9 & 1.0 & 1.3 & 95 & 0.2 & 0.32 & 1.4 & 77 & 1.2 & 10 & 1.3 \\
\hline SbR & SW & 10.38 & 1.8 & 1107 & 2.2 & 13.8 & 2.5 & 0.67 & 4.1 & 0.1 & 6.8 & 2.8 & 2.5 & 534 & 0.8 & 8.61 & 2.3 & 797 & 2.4 & 40 & 2.4 \\
\hline GamV & SW & 2.39 & 14.3 & 50 & 14.8 & 5.3 & 14.9 & 0.81 & 16.1 & 0.1 & 31.6 & 1.8 & 15.2 & 252 & 1.1 & 1.14 & 15.9 & 306 & 14.2 & 11 & 14.8 \\
\hline GamS & SW & 0.83 & 25.7 & 26 & 20.3 & 1.1 & 24.3 & 0.46 & 33.1 & 0.3 & 29.6 & 1.4 & 23.5 & 112 & 1.3 & 0.52 & 28.2 & 71 & 20.3 & 4 & 25.8 \\
\hline GamM & SW & 1.10 & 3.5 & 19 & 0.4 & 1.3 & 2.3 & 0.61 & 5.5 & 0.5 & 4.4 & 1.5 & 2.3 & 77 & 0.6 & 0.64 & 3.1 & 98 & 0.5 & 6 & 5.0 \\
\hline
\end{tabular}

Table 6. Statistics on trace elements contents in water from different aquifer types.

\begin{tabular}{|c|c|c|c|c|c|c|c|c|c|c|c|c|c|c|c|c|}
\hline \multirow[t]{2}{*}{ Type } & \multicolumn{4}{|c|}{ Granites } & \multicolumn{4}{|c|}{ Schistes et Volcano-sediment } & \multicolumn{4}{|c|}{ Mafic volcanic } & \multicolumn{4}{|c|}{ Surface water } \\
\hline & Min & Max & Median & $\mathrm{n}$ & Min & Max & Median & $\mathrm{n}$ & Min & Max & Median & $\mathrm{n}$ & Min & $\operatorname{Max}$ & Median & $\mathrm{n}$ \\
\hline Al & 16 & 700 & 257 & 9 & 12 & 166 & 55 & 6 & 7 & 813 & 104.5 & 6 & 71 & 797 & 98 & 5 \\
\hline Cd & 0 & 0.8 & 0.1 & 9 & 0.1 & 0.9 & 0.35 & 6 & 0.1 & 1.4 & 0.45 & 6 & 0 & 0.5 & 0.1 & 5 \\
\hline $\mathrm{Cr}$ & 0.69 & 3.87 & 1.61 & 9 & 0.54 & 1.43 & 1.1 & 6 & 0.65 & 7.72 & 3.55 & 6 & 0.61 & 10.38 & 1.1 & 5 \\
\hline Mn & 5 & 120 & 20 & 9 & 2 & 166 & 25.5 & 6 & 39 & 643 & 118.5 & 6 & 19 & 1107 & 26 & 5 \\
\hline $\mathbf{F e}$ & 73 & 443 & 181 & 9 & 59 & 244 & 168 & 6 & 41 & 207 & 109.5 & 6 & 77 & 534 & 112 & 5 \\
\hline Co & 0.26 & 2.41 & 0.44 & 9 & 0.23 & 1.04 & 0.56 & 6 & 0.37 & 210.2 & 2.84 & 6 & 0.32 & 8.61 & 0.64 & 5 \\
\hline $\mathbf{P b}$ & 1 & 6.8 & 1.5 & 9 & 1 & 2 & 1.4 & 6 & 1 & 4.1 & 1.9 & 6 & 1 & 2.8 & 1.5 & 5 \\
\hline As & 0.19 & 1.83 & 0.51 & 9 & 0.28 & 4.39 & 1.57 & 6 & 0.26 & 1.75 & 0.7 & 6 & 0.31 & 0.81 & 0.61 & 5 \\
\hline Zn & 4 & 2393 & 9 & 9 & 7 & 30 & 20 & 6 & 9 & 77 & 30.5 & 6 & 4 & 40 & 10 & 5 \\
\hline $\mathbf{N i}$ & 1.2 & 4.3 & 2 & 9 & 1.7 & 4.1 & 3 & 6 & 1.8 & 890.2 & 8.45 & 6 & 1.1 & 13.8 & 1.6 & 5 \\
\hline
\end{tabular}


such as $\mathrm{As}, \mathrm{Cd}, \mathrm{Fe}, \mathrm{Pb}$, and $\mathrm{Zn}$ are present in amounts not exceeding standards for drinking water and their concentrations in the waters depend on geology settings (Table 6).

PCA (Figure 8(a), Figure 8(b)) shows that first principal component (F1 axis) contributes for 32\% of the total variance in the data set and essentially, controls the water mineralization. Elements that contribute significantly to this axis are: $\mathrm{Ni}, \mathrm{Co}, \mathrm{Mn}, \mathrm{Cr}$, and $\mathrm{Al}$. The second principal component which accounts for $22 \%$ of the total variance in the data has weighted factors) determined by the Fe and Cd that contribute significantly to F2 axis. $\mathrm{Mn}$ and $\mathrm{Cr}$ are well correlated which may suggest a common origin of these two elements. Much of natural $\mathrm{Cr}$ is derived from chromite $\left(\mathrm{FeCr}_{2} \mathrm{O}_{4}(\mathrm{~s})\right)$ which is relatively insoluble [22]. $\mathrm{Cr}$ and $\mathrm{Mn}$ contents at the Sabodala stream show a pollution at this level (Figure 8(a), Figure 8(b)). Mn enrichment in water and especially the soluble $\mathrm{Cr}$ may occur in sediments or other evaporative lakes environments as trace element within other soluble salts [25]. In contrast, $\mathrm{Ni}$ and Co ions are well correlated this reveals another source of pollution at Sabodala. Ni is often associated with Co in nature, their occurrence is specially noted in ultramafic rocks, black shales but also in nickel or silver deposits and waters affected by mining wastes [26]. Very high Ni concentrations observed at Sabodala could occur from mining waste (tailings) which, when leached can contaminate well waters at this village. This is confirmed by a decrease in $\mathrm{pH}$ in Sabodala well waters where, the lowest $\mathrm{pH}$ values 5.3, 5.8 and 5.5 at Sabodala P3, Sabodala P2 and Sabodala P4, respectively. Finally F3 axis is characterized by weighted factors such as $\mathrm{Zn}^{2+}$ and $\mathrm{Pb}^{2+}$ that contribute significantly to the third principal component accounts for $14 \%$ of the total variance in the data. The only sample encountered in this group and localized in Saraya granite is characterized by $\mathrm{Zn}$ and $\mathrm{Pb}$ contents relatively high. This high concentration is accompanied to an increase in $\mathrm{SO}_{4}^{2-}$ concentration in water which can probably due to sulfides weathering $\left(\mathrm{ZnSO}_{4}\right)$ and $\left(\mathrm{PbSO}_{4}\right)$ in the granites.

Cluster distribution (Figure 9) identifies three groups:

Cluster 1 which includes waters with very low contents of MTE below the thresholds of allowable concentrations for drinking water. This cluster includes all boreholes, surface waters excepted Sabodala River, downstream of Bantako on the Gambia River and wells that are unpolluted mainly localized in areas without mining activities;

Cluster 2 which contains water from gold mining areas except Saraya well is characterized by more enriched waters in trace element including aluminum. This relatively high $\mathrm{Al}$ contents in waters in mining area are related to gold ore washing and leaching which contributes significantly to release $\mathrm{Al}$, major elements of rocks in solution, thereby tending to increase its concentration in waters;

Finally, cluster 3 represents polluted waters which are characterized by high Ni contents at Sabodala P3, very

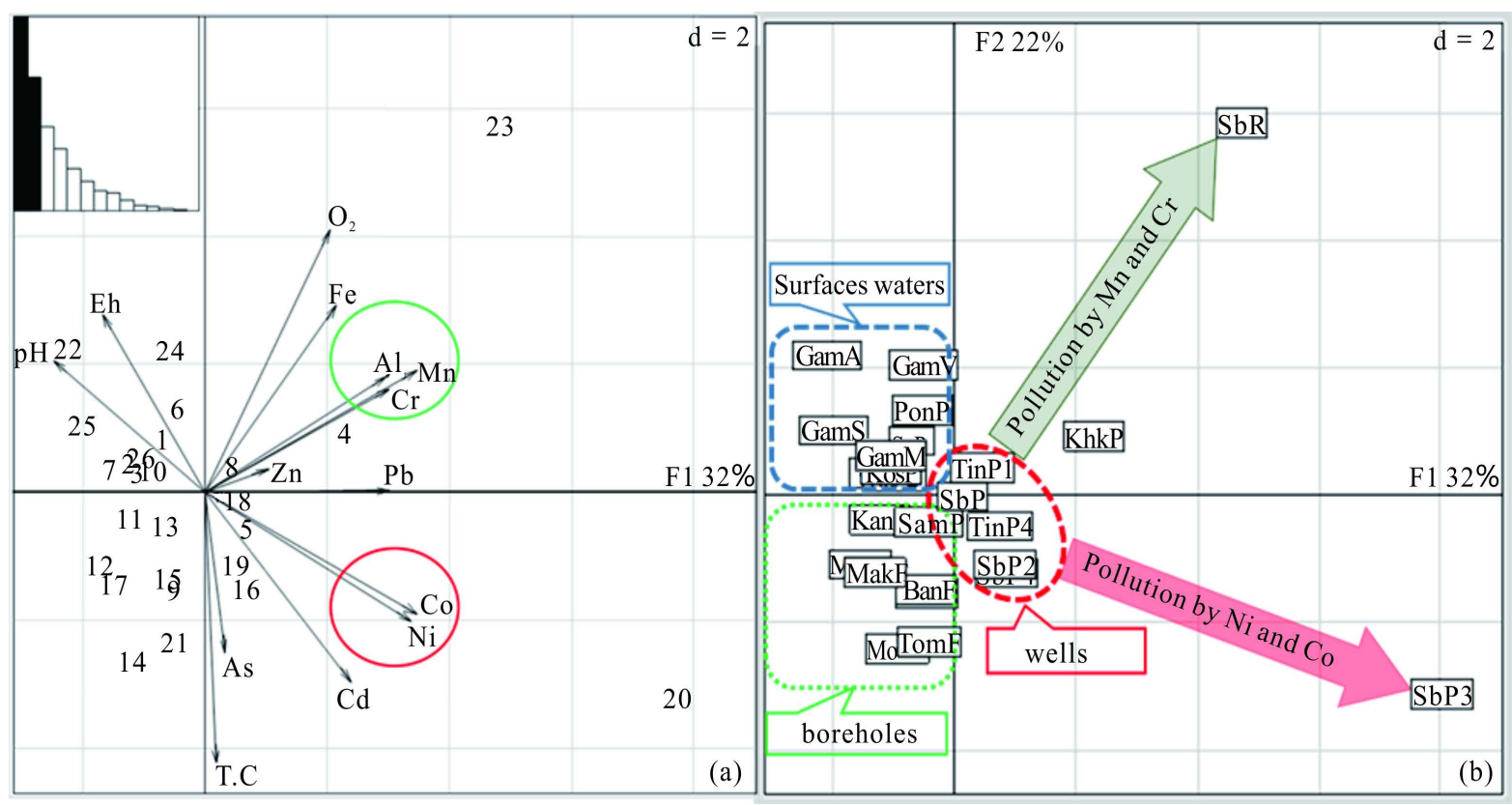

Figure 8. Principal components analysis (PCA) of trace elements (Ni, Cr, $\mathrm{Al}, \mathrm{Mn}, \mathrm{Co}, \mathrm{Cd}, \mathrm{Fe}, \mathrm{Zn}, \mathrm{Pb})$ in waters from different reservoirs (numbers represent the sampling sites: see Table 4). 


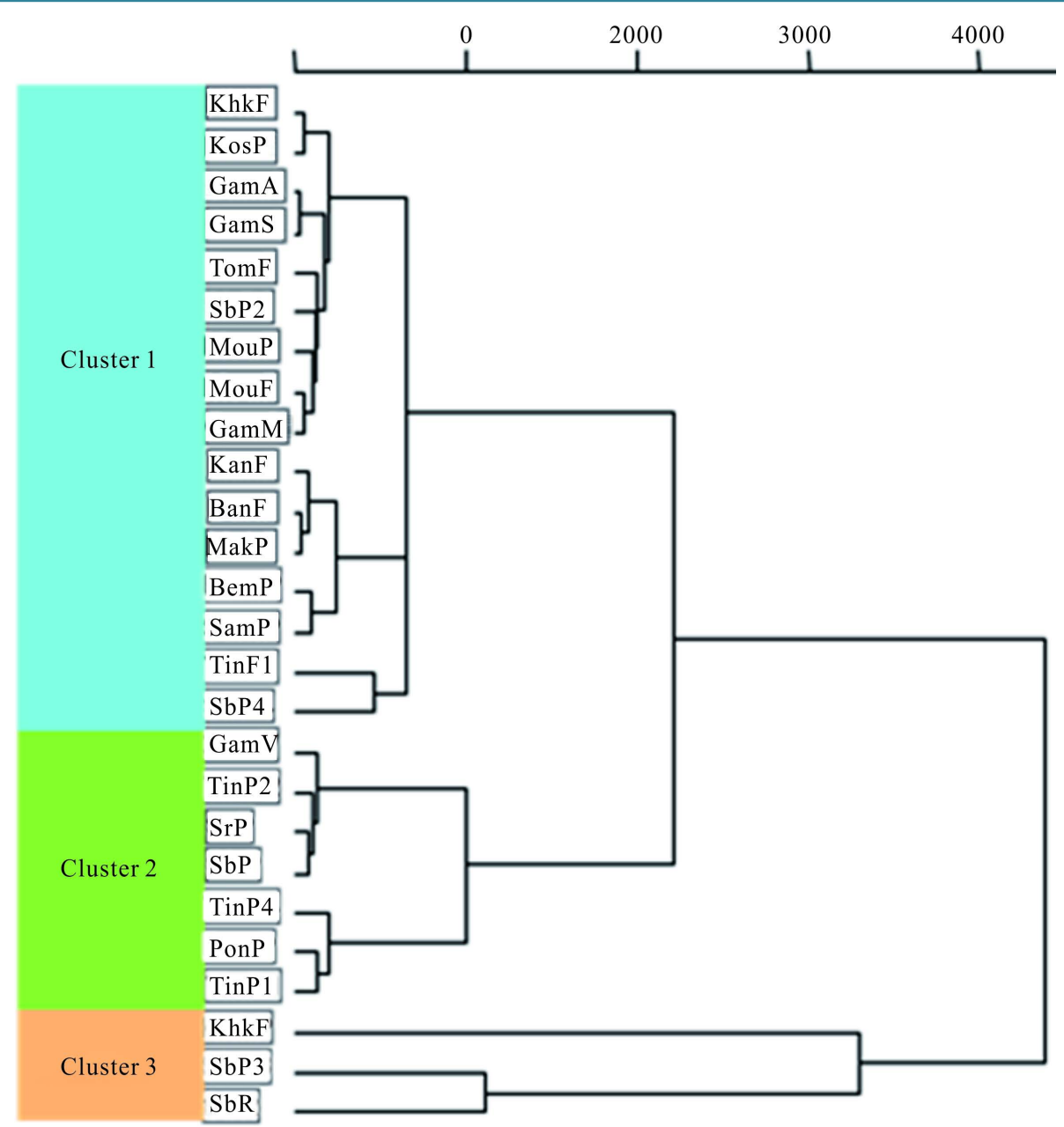

Figure 9. HCA different water groups from different reservoirs taking into account their composition in trace elements (Ni, Cr, Al, Mn, Co, Cd, Fe, Zn, Pb).

high Mn content at Sabodala River and relative high contents of Zn $\left(2393 \mu \mathrm{g} \cdot \mathrm{L}^{-1}\right)$ and $\mathrm{Pb}\left(6,8 \mu \mathrm{g} \cdot \mathrm{L}^{-1}\right)$ at Khodonkhou.

\section{Conclusion}

This study based on the hydrochemical characterization of hydrogeological units in eastern Senegal by statistical approach incorporates major and trace elements. Multivariate geostatistical analysis by PCA showed two main sources of water mineralization for the major elements. A first natural source characterized by $\mathrm{Ca}-\mathrm{Mg}-\mathrm{HCO}_{3}$ and $\mathrm{Na}-\mathrm{HCO}_{3}$ types observed at boreholes and unpolluted surface waters and a second anthropogenic source related to their high nitrates contents mainly observed in village wells that tap the upper weathered aquifers. Granites GW are less mineralized and are enriched in alkali $(\mathrm{Na}+\mathrm{K})$, while schistes and volcano-sediments $\mathrm{GW}$ and mafic volcanic GW more mineralized, are characterized by higher contents of alkaline earth $(\mathrm{Ca}+\mathrm{Mg})$. These results show that well waters of eastern Senegal are vulnerable and often affected by pollution and this due to human activities observed in the gold mining areas (Tinkoto, Sabodala and Bantako) where, most enriched waters in MTE particularly Al are noted. Results indicate that, at eastern Senegal the upper weathered aquifers are highly vulnerable to pollution as shown by well waters often affected by pollution related human activities observed in gold mining areas. Therefore, consumption in long term of these contaminated well waters could cause health effects to population that is exposed to these relatively high $\mathrm{NO}_{3}$ and trace element concentrations especially at Sabodala village where, further investigations should be conducted in order to better manage monitoring and assessment of drinking-water quality in community supplies. 


\section{Acknowledgements}

We are grateful to all those who have contributed to this manuscript. The authors thank Mr. Moussa Sow, research engineer at water chemistry laboratory UCAD who performed major elements analysis, Dr. Seyni SANE for his kind support for statistical data processing.

\section{References}

[1] Morisseau, M., Kaisin, J., Diallo, D.P., Ndiaye, P.M., Dioh, E., Dabo, B., Barry, T.M., Fall, M., Ndiaye, F., Diagne, E. and Diatta, F. (2010) Carte Gîtologique et abondance Or à 1/500000 du Sénégal oriental. Ministère des Mines, de l'Industrie, de l'Agro-Industrie et des PME, Direction des Mines et de la Géologie, Dakar.

[2] Nriagu, I.O. (1990) Global Metal Pollution. Environment, 32, 7-33. http://dx.doi.org/10.1080/00139157.1990.9929037

[3] Sasamoto, H., Arthur, R.C. and Hama, K. (2011) Interpretation of Undisturbed Hydrogeochemical Conditions in Neogene Sediments of the Horonobe Area, Hokkaido, Japan. Journal Applied Geochemistry, 26, 1464-1477.

[4] Khan, T.A. (2011) Trace Elements in the Drinking Water and Their Possible Health Effects in Aligarh City, India. Journal of Water Resource and Protection, 3, 522-530. http://dx.doi.org/10.4236/jwarp.2011.37062

[5] Bassot, J.P. (1987) Le complexe volcanoplutoniquecalco-alcalin de la Dalema (Est Sénégal): Discussion de sa signification géodynamique dans le cadre de l'orogénie éburnéenne (Protérozoïque inférieur). Journal of African Earth Science, 6, 109-115.

[6] Bassot, J.P. (1966) Étude géologique du Sénégal Oriental et de ses confins Guinéo-maliens. Mémoire Bureau de Recherches Géologiques et Minières, Paris, 40, 322 p.

[7] Théveniaut, H., Ndiaye, P.M., Buscail, F., Couëffé, R., Delor, C., Fullgraf, T. and Goujou, J.-C. (2010) Notice explicative de la carte géologique du Sénégal oriental à 1/500000. Ministère des Mines, de l’Industrie, de l’Agro-Industrie et des PME, Direction des Mines et de la Géologie, Dakar.

[8] Sustrac, G. (1984) Plan minéral de la République du Sénégal. Ministère du Développement industriel et de l’artisanat, Direction des Mines et de la Géologie, 3 Volumes, 725 p.

[9] Mall, I. (2009) Contribution à l'étude hydrogéochimique des aquifères de socle: Cas du Sénégal oriental. Mémoire D.E.A Ucad, 80 p.

[10] Camus, H. and Debuisson, J. (1964) Etude hydrogéologique des terrains anciens du Sénégal Oriental. Campagne 19621963. Rapport. B.R.G.M, Dak, 143 p.

[11] Diouf, S. (1999) Hydrgéologie en zone de socle cristallin et cristallophyllien du Sénégal oriental. Application de la méthode électrique $1 \mathrm{D}$ et 2D à la localisation et à la caractérisation des aquifères du batholite de Saraya et ses environs. Thèse de doctorat de 3ecycle, Univ. C.A.D., de Dakar, 86 p.

[12] Potot, C. (2011) Etude hydrochimique du système aquifère de la basse vallée du Var. Apport des éléments traces et des isotopes ( $\left.\mathrm{Sr}, \mathrm{Pb}, \delta^{18} \mathrm{O},{ }^{226},{ }^{228} \mathrm{Ra}\right)$. Thèse Université de Nice-Sophia Antipolis, Nice, $202 \mathrm{p}$.

[13] Wuilleumier, A., Mall, I. and et Ndiaye, P.M. (2010) Carte hydrogéologique à 1/500000 du Sénégal oriental. Ministère des Mines, de l'Industrie, de l'Agro-Industrie et des PME, Direction des Mines et de la Géologie, Dakar.

[14] Hyndman, D.W. (1985) Petrology of Igneous Rock and Metamorphic Rocks. McGraw-Hill, New York, 786 p.

[15] Frape, S.K. and Blyth, A. (2003) Deep Fluids in the Continent: II. Crystalline Rocks. In: Drever, J.I., Holland, H.D. and Turekian, K.K., Eds., Surface and Groundwater, Weathering, and Soils, Vol. 5, Treatise on Geochemistry, Elsevier-Pergamon, Oxford, 541-580.

[16] Appelo. C.A.J. and Postma, D. (2009) Geochemistry, Groundwater and Pollution. 2nd Edition, A.A. Balkema Publishers.

[17] Garrels, M.R. and Mackenzi, F.T. (1971) Evolution of Sedimentary Rocks. Norton, New York, 397 p.

[18] Bricker, O.P., Jones, B.F. and Bowser, C.J. (2003) Mass-Balance Approach to Interpreting Weathering Reactions in Watershed Systems. In: Drever, J.I., Holland, H.D. and Turekian, K.K., Eds., Surface and Groundwater, Weathering, and Soils, Vol. 5, Treatise on Geochemistry, Elsevier-Pergamon, Oxford, 119-132.

[19] Alley, W.M. (1993) Regional Groundwater Quality. Van Nostrand Reinhold, New York.

[20] Laaksoharjua, M., SkaÊrmana, C. and SkaÊrmanb, E. (1999) Multivariate Mixing and Mass Balance (M3) Calculations, a New Tool for Decoding Hydrogeochemical Information. Applied Geochemistry, 14, 861-871.

[21] ADEME (2010) Sites pollués et sols, accessible sur le site internet. http://www.ademe.fr

[22] INERIS (2006) Eléments traces métalliques: Guide méthodologique. Rapport d'études INERIS-DRC-06-66246/DESPR01a.

[23] WHO (2008) World Health Organization, Guidelines for Drinking-Water Quality, Vol. 1, 3rd Edition Incorporating 1st 
and 2nd Addenda. http://www.who.int/water_sanitation_health/dwq/gdwq3rev/en/index.html

[24] European Council (1998) Drinking Water Directive 98/83/EC on the Quality of Water Intended for Human Consumption. OJL, 330, 32-54.

[25] ATSDR (1997) Toxicological Profiles for Nickel. Agency for Toxic Substances and Disease, Atlanta.

[26] Plumlee, G.S. and Ziegler, T.L. (2003) The Medical Geochemistry of Dusts, Soils and Other Earth Materials. In: Lollar, B.S., Holland, H.D. and Turekian, K.K., Eds., Environmental Geochemistry, Vol. 9, Treatise on Geochemistry, Elsevier-Pergamon, Oxford, 263-310. 
Scientific Research Publishing (SCIRP) is one of the largest Open Access journal publishers. It is currently publishing more than 200 open access, online, peer-reviewed journals covering a wide range of academic disciplines. SCIRP serves the worldwide academic communities and contributes to the progress and application of science with its publication.

Other selected journals from SCIRP are listed as below. Submit your manuscript to us via either submit@scirp.org or Online Submission Portal.
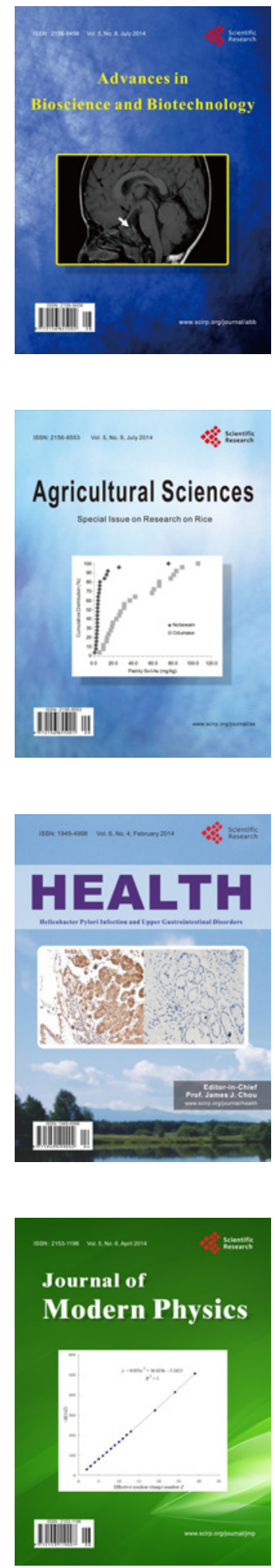
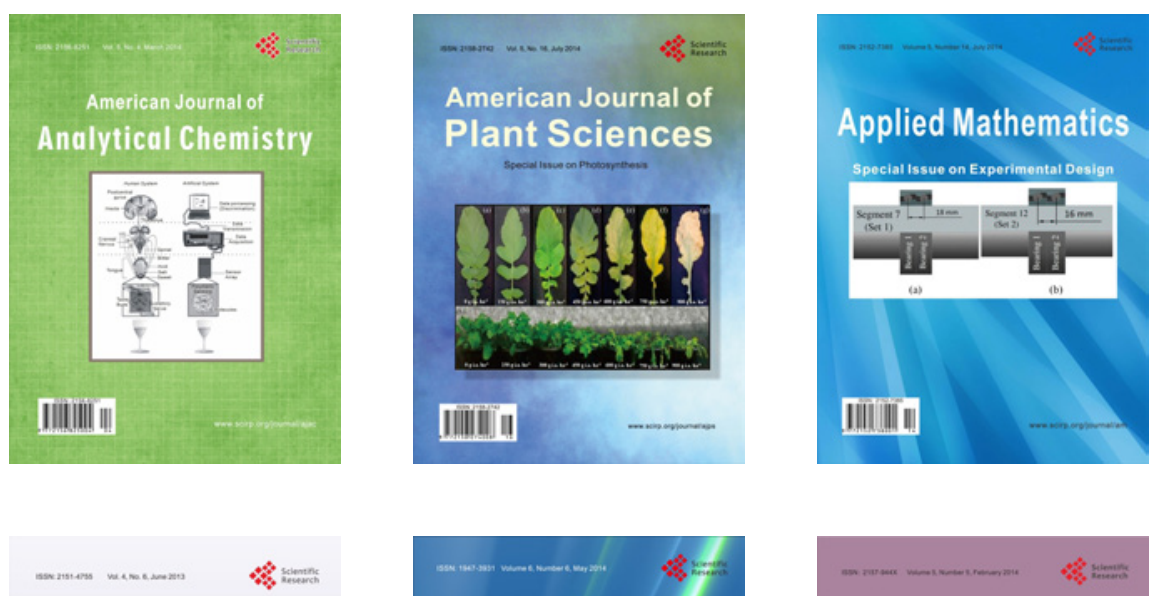

Creative Education
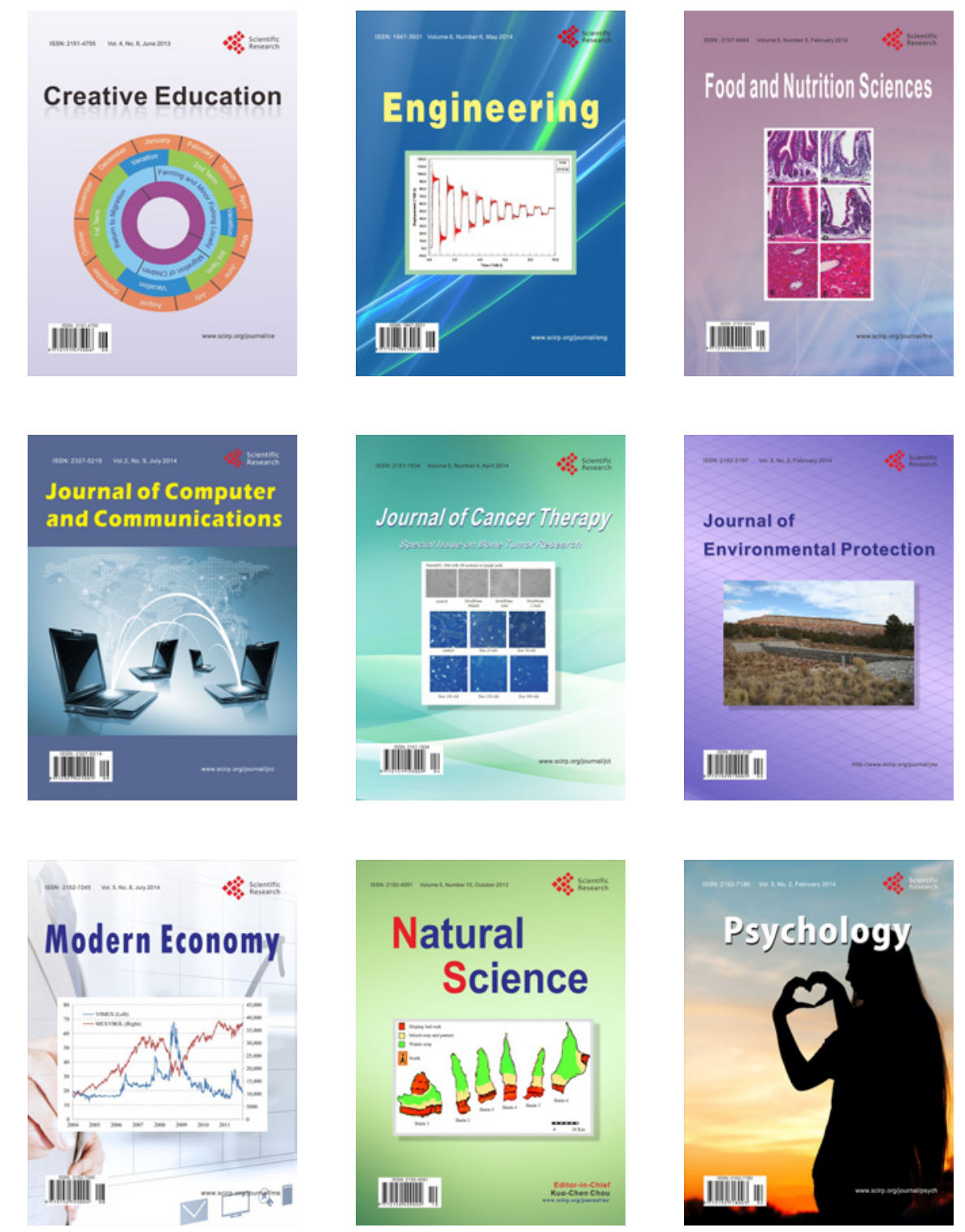